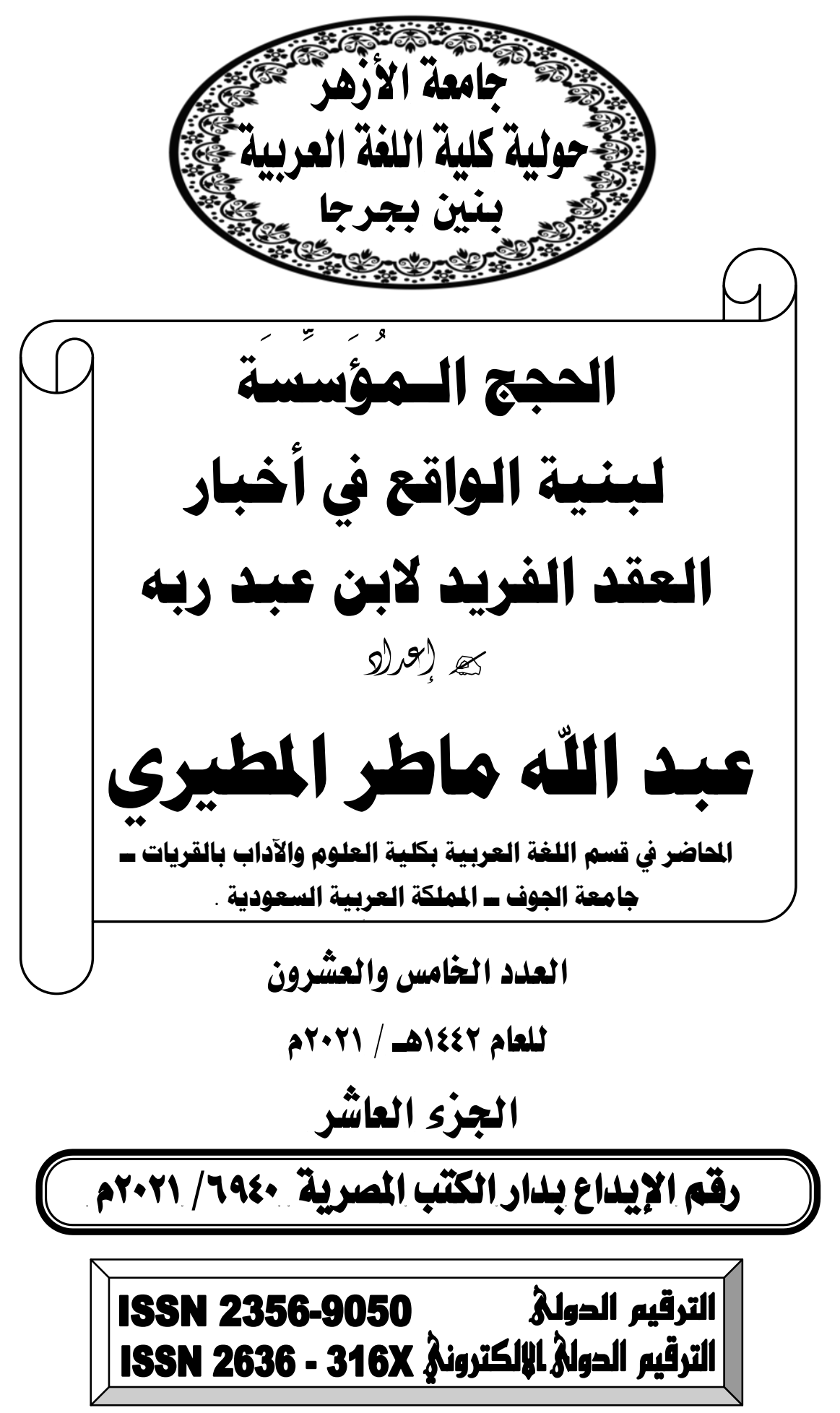




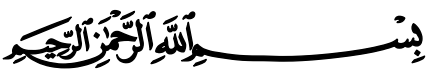

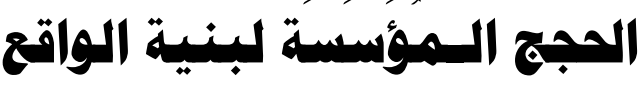 \\ في أخبار الهقد الفربد لابن عبد ربه}

عبد الاله ماطر الاطيزي

قسم اللغة العربية بكلية العلوم والآداب بالقريات ـ جامعة الجوف = المملكة العربية

السعودية.

المالمص

تنتاول هذه الاراسة المعنونة " بالحجج المؤسِّسَة لبنية الواقع" ملمحًا

بارزًا في كتاب العقد الفريد، حيث جاءت الصورة القنية، واستدعاء المثال مرتبطين بالوظيفة الإقناعية أكثر من ارتباطها بالوظيفة التزيينية والتوضيحية. ولقد قام هذا المقال على محورين رئيسين: ينصرف الأول إلى دراسة المثال ودوره البارز في العملية الحجاجية، ويتناول المحور التثاني الصورة القنية من خلال ارتباطها بوظيفة الإقناع. الكلهات الافتاحية : الخبر، ابن عبد ربه، حجة، المثال، الصورة . 


\section{Arguments founding}

the structure of reality in the news of the unique contract of Ibn Abd Rabbo

\section{Abdullah Mater Al-Mutairi}

Lecturer in the Department of Arabic Language, College of Science and Arts in Al-Qurayyat, Al-Jouf University, Kingdom of Saudi Arabia.

Email: amalmoteeri@ju.edu.sa

\section{$\underline{\text { Abstract }}$}

This article, entitled "The Arguments Establishing the Structure of Reality" deals with a prominent feature in ALAGAD ALFAREED book, where the artistic image and the invocation of the example are related to the persuasive function more than it is to the ornamental and illustrative functions. This article is based on two main aspects: the first aspect focuses on the study of the example and its prominent role in the argumentative process, and the second aspect deals with the artistic image through its connection with the function of persuasion.

Keywords : news, Ibn Abd Rabbo, Hajjah, example, image .

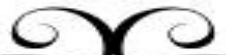




\section{الاقدهمة}

الحمد لله والصلاة والسلام على رسول الله، وبعد.

فبعد التأمل في النتاج النثري في مجموعة من المؤلقات الألدلسية، وما

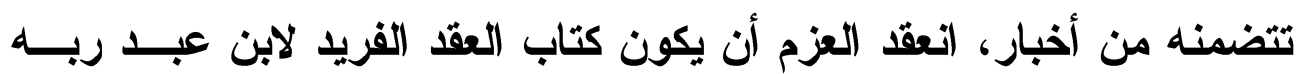
الأدلسي محورًا لهذه الار اسة ـ وقد رأى الباحث أن المقاربة الحجاجية هي المدخل الأسب لهذا الجنس الأدبي، وسأستنير في هذا البحث بمقاربة شايم

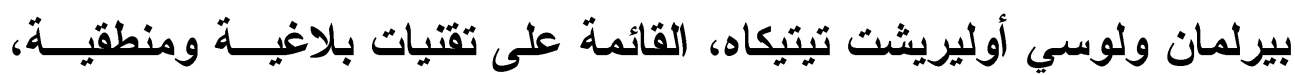
والتي بلورها تستدعي تحديد الســياق التواصــلي، باستحضــار أطــر اف

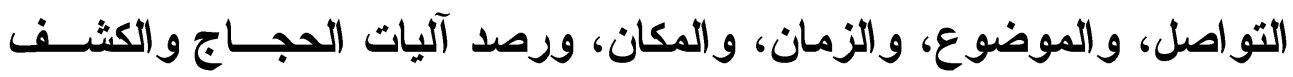
عن طريقة اثتنغالها داخل الخطاب، وما تؤديه حجاجية الصور من دور فـي تحديا وجهات النظر، وكثف المضمر، وماينطوي عليه الخطاب من مقاصد إقناعية، وتأثيرية وغيرها. أهميهية البحث وقيسمتهـ: تتمثل أهمية هذا البحث في لفته النظر إلى حجاجية الصورة في الخبر الأدبي من خلال كتاب العقد الفريد وهناك عدة أسباب دفعتني إلى اختيار هذا الموضوع، وهي كالتالي: - الرغبة في الوقوف على أساليب الحجاج، وآلياته في مدونة البحث. - عدم وجود در اسة تناولت حجاجية صورة الخبر في كتاب العقد الفريد.

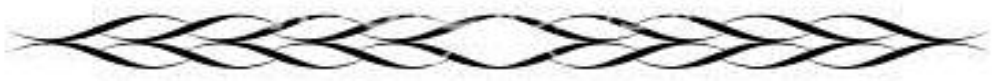




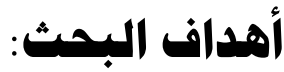

- الوقوف على ماتؤديه الأمثال والحكم من دور في حمل المتلقي علـى الاقي الاقتناع.

- كثف دور الصورة في العملية الإقناعية.

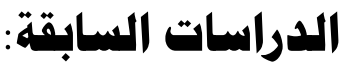

توجل بعض الدراسات التي تناولت الحجاج في الخبر الأندلسي، وأهـــ

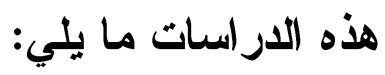

1- دراسة بعنوان (الحجاج في الخبر الأندلســي) حجاجيــة التخييـل

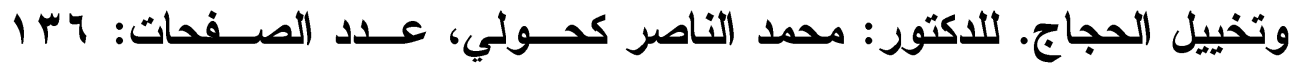

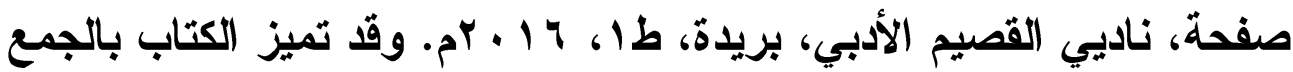

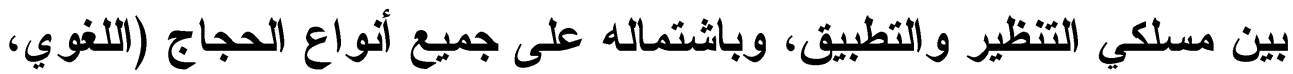
و الخطابي، والبلاغي، و التذاولي) و التطرق إليها بشــكل مختصــر ومركـز .

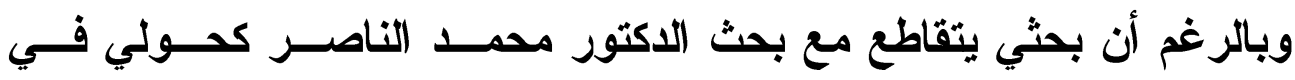

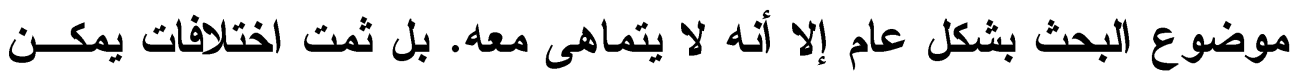

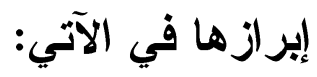

- اعتمد البحث على جزئية محددة تتمثل في معالجة العجج المؤسسّة

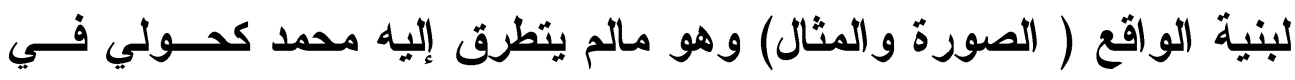

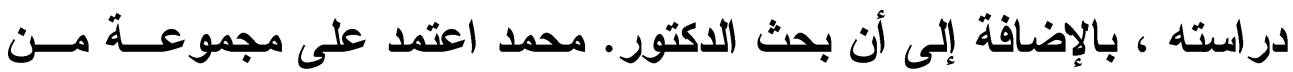

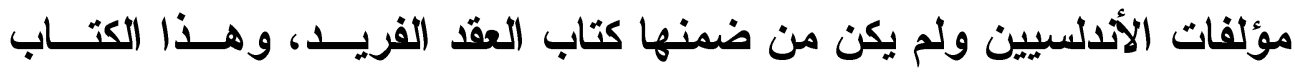
ماسأعتمده في بحثي بشكل خاص. 


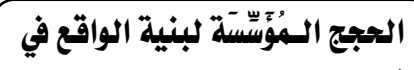

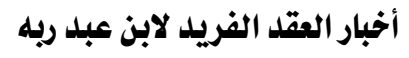
الجزء العاشر الجأرون

\section{هنهمج البصث وإجراءاته:}

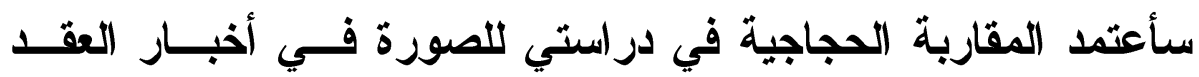
القريد، من خلال مقاربة شايم بيرلمان ولوسي أوليريشت تيتيكاه، القائمسـة على تقنيات بلاغية ومنطقية، وما تؤديه من دور في تحديا وجهات النظـــر، وكشف ما ينطوي عليه الخطاب من مقاصد إقناعية، وتأثيرية.

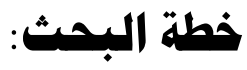

رأى الباحث أن يقيم بحثّه من خلال مقدمة، ومبحثين وثثبث للمصادر. المقدمة وتثضمن: أهمية الموضوع، وأسباب اختياره، وأهدافه، والدراسات السابقة، والمنهج المتبع، وخطة البحث. - التهمهيد: المنطhلقات المباجية - المبحث الأول: هماجية الصمرة. - البمشث الثاني: هباجية المثال.

والله تعالى أسأله التوفيق والسداد، وما توفيقي إلا بالله عليه توكلـــ و إليه أنيب، وصل اللهم وبارك على نبينا محمد وعلى آله وصحبه أجمعين. الباحث

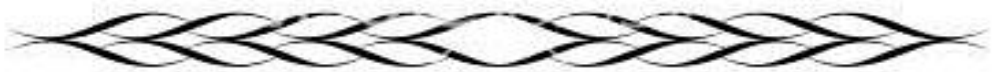




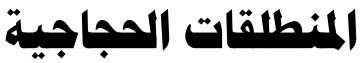

يـهف الحجاج إلى "جعل العقول تذعن لما يطرح عليها، أو يزيد فـي درجة الإذعان، فأنجع الحجاج ما وفق في جعل حدة الإذعان تقوى درجتهـــا لاى السامعين، بشكل يبعثهم على العمل المطاــوب إنجــازه، أو الإمســاك

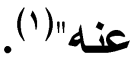

والقدرة على الإقتاع تتأتى من خلا انطلاقها من مقدمات يبني عليهــا المحاج خطابه الإقناعي، فعرض الحجج لا يكون له الأثر الفعال ما لم يحسن المحاج الاستفادة من المقدمات الحجاجية، حيث تعد البوابة الرئيسية التـي تمر منها الحجج إلى المتلقي "إنَّ قوة حجة ما مشروطة باعتناق الســامعين لمقدمات الحجاج، وبملانمة هذه المقدمات للموضوع، وعلاقتها القريبــة أو إو البعيدة بالادعوى المدافع عنها، وكذلك بالاعتر اضات التي قد تواجــهـ بهــا، وبالطريقة التي يمكن بها تقنيد هذه الاعتر اضات. معنى هذا أنَّ قوة الحجــة تتحدد بنجاعتها لا بصحتها، أي في قرتها على الفعل فيمن تتوجه إليهم(؟). وأهم هذه المقدمات أو المنطلقات الحجاجية هي:

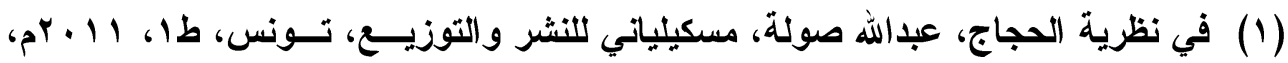
ص ص 1. (r) ينظر: نظرية الحجاج عند شاييم بيرلمان، الحسين بنو هاثم، دار الكتاب الجديدة المتحدة،

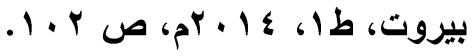

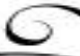




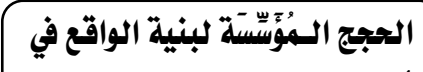
أخبار العقد الفريل لابن عبد ربله

وهي الأحداث التي تقع أمام أعين الناس، فيتفةــون علــى وجودهـــا، ويتخذون منها مـادة للحجاج، وهي وقائع حســية، أو مفترضـــة، يســوقها

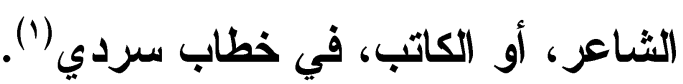

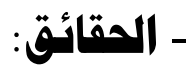

وهي أنظمة أكثر تعقيدًا من الوقائع، ومدارها على مفاهيم فلسفية، أو

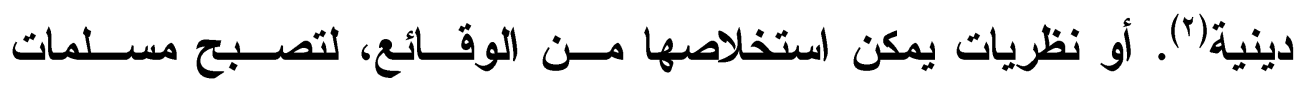
ضرورية، ففي هذا البيت من قصيدة المتنبي:

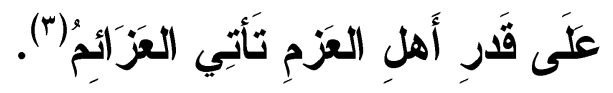

حقيقة نظرية استخلصها أبو الطيب من وقائع حروب ســيف الدولــة المتكررة، ولا يخفى على القارئ أنّ الحجاج بالحقائق أبعد ثنأثيرًا من الحجاج

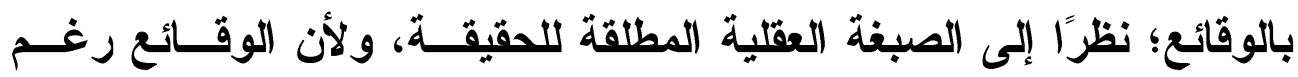
قيمتها الإقناعية العالية جزع دال على حقيقة جزئية ظرفية، أما الحقيقة فهي كلي عام مستخلص من الوقائع المتكررة عبر الزمن(\&).

(1) ينظر: التواصل الأدبي من التذاولية إلى الإدراكية، صـالح رمضــان، النــادي الأدبـي،

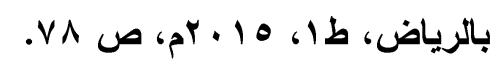

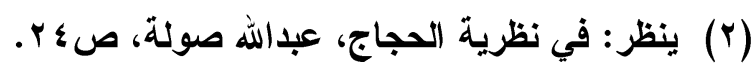

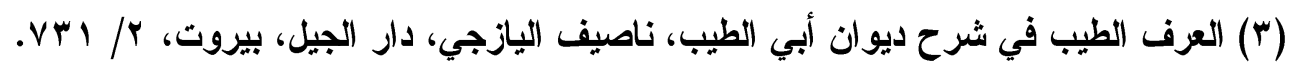

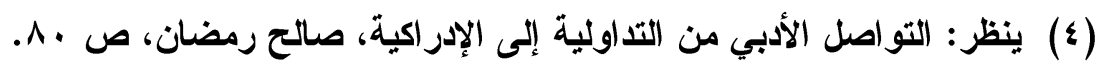




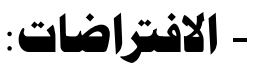

تحظى الافتراضات -شأنها شأن الحقائق والوقائع - بالمو اققة العامة،

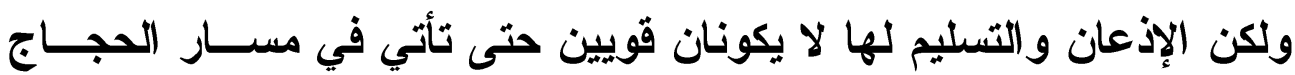
عناصر أخرى تقويهما، فإكرام الضيف بطبخ الطعام في آخر الليل أو بالأبح

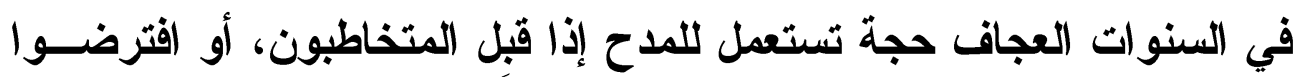

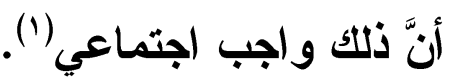

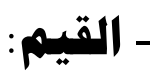

هي المحور الأي يعتمد عليه الحجاج؛ لأهها حاضرة في كـل حقـول المعرفة، وتنقسم إلى قسمين: - قيم مجردة كالجمال، والعدل، والحق. - قيم ملموسة كقيمة الوطن مثنًا (؟). ويرى "صالح رمضان" أنَّ القيم لا

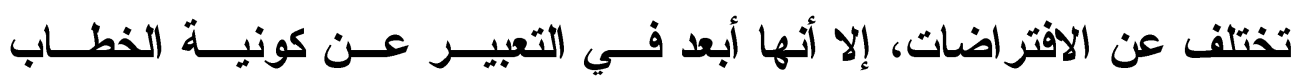
الحجاجي، وأيسر تناولًا في الحجاج الموجه إلى مخاطب كوني (ن). - التزاتبيات والهرهيات: التراتبيات و الهرميات مرتبطة بالقيم "وهي نوعان: - مجردة، مثل اعتبار العدل أفضل من النافع.

(1) ينظر : التواصل الأدبي من التداولية إلى الإدراكية، صالح رمضان، ص • ـ.

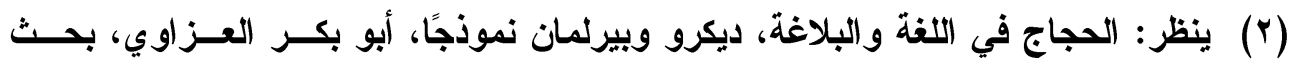

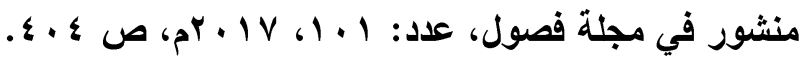

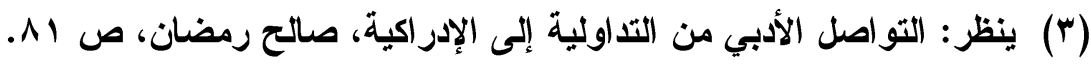


- مادية محسوسة، كاعثبار الإنسان أفضل درجة من الحيوان، والإله

أفضل درجة من الإنسان" (1")

ويمكن للقيم أن تتراتب إذا كان في المجتمع أكثر من تصور اجتماعي، فقد حرصت المجتمعات التي تعيش على القتص والصيد على التغتي بقيمــة الشجاعة؛ نظرًا لنقعها العام، وحاجة المجتمع البدوي إليها(؟).

- المواضع -

المواضع في نظرية بيرلمان تقابل مسلمات الاســتلال فــي المنطـق

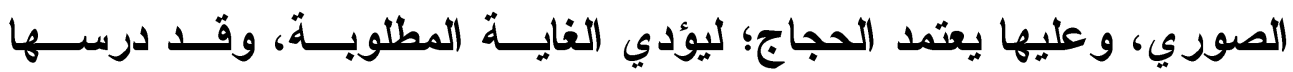
بيرلمان بوصفها من مقدمات الحجاج ومنطلقاته("). ويمكن تقسيم المواضع

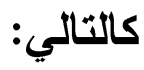

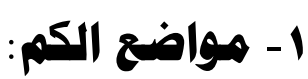

وهي المواضع التي تثبث أنّ شيئًا أفضل من شيء لأسباب كمية، مثال ذلك: أنّ المال الأوفر أفضل من المال الأقل وفرة، والمال الأي يفيـــ عـدـدًا كثيرًا من الناس أفضل من المال الأي يفيد عددًا قليلًا من النــاس، وهكـــا دواليك(؛). وقد أطلق "صالح رمضان" على هذا النوع من الحجاج "الحجـــاج بالحجم"، وعلّ ذلاك أنّ الكم لا يمثل إلا جزعًا من ذلك الموضع حيث يقــول:

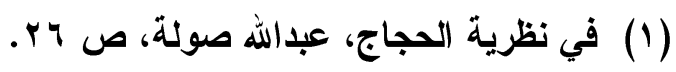

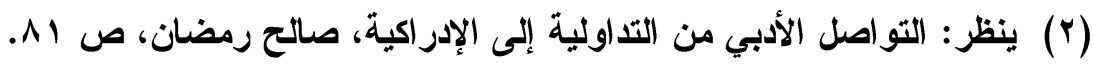

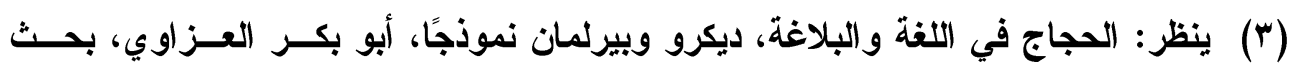

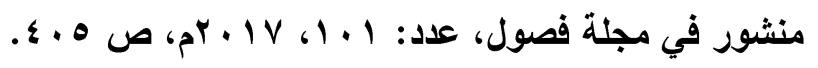

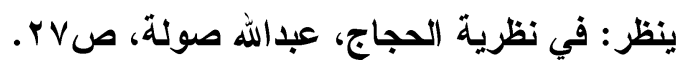


"و إنما الصواب عندنا هو الحجم أي الكم بمختلف أبعاده، بالعدد، وبــالطول،

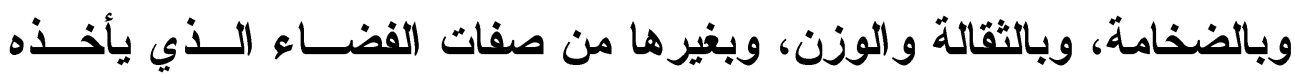

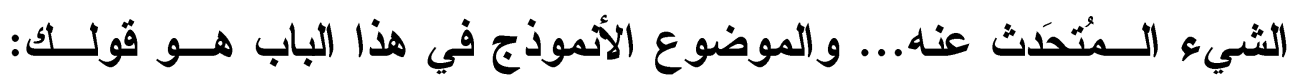

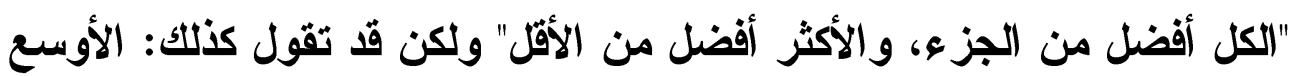

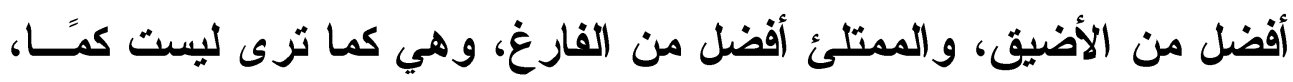

$$
\begin{aligned}
& \text { و إنما هي حجم"(') } \\
& \text { r- هواضع الكيف: }
\end{aligned}
$$

وهي التي تستمد قيمتها من وحدانيتها وتميزها، مثل: الحق الــــي لا

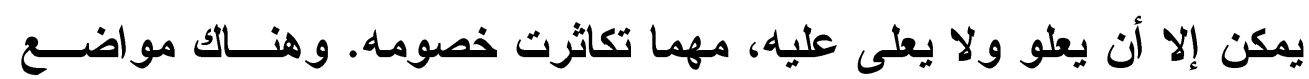

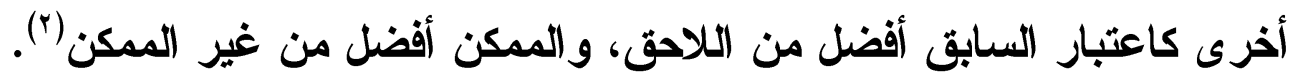
ويمكن أن نتناول الحجج الــؤُسَسِّةَة لبنية الواقع من خلال مبحثين:

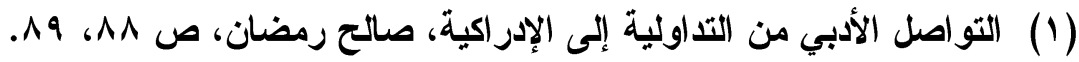

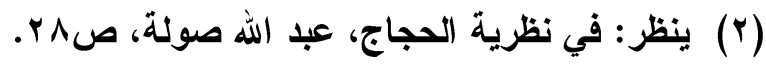




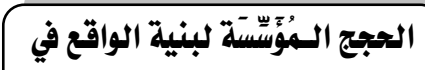 أخبار العقد الفريل لابن عبل ربله}

\section{ا- المبحث الأول: تأسيس الواقع بواسطة المالات الخاصة (الإثال):}

يتأسس الحجاج على مثال؛ يمكن توسيعه ليصبح حالة عامــة، حيــث

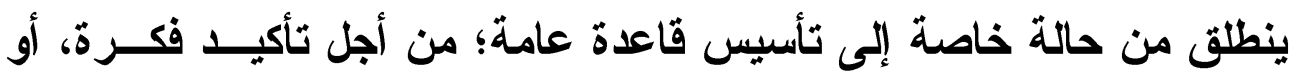

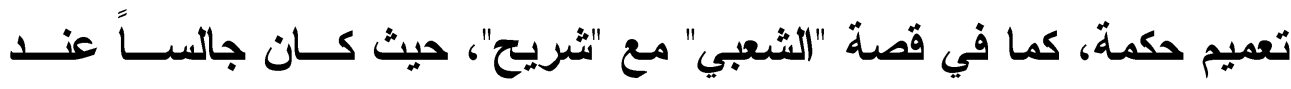
"ثريح"، إذ دخلت عليه (مرأة تشكو زوجها، وهــو غائــب وتبكـي، فة فــال "الثعبي": ما أراها إلا مظلومة، قال "شريح": وما علمُك؟، قال: لبكائها، قال:

إن أخوة يوسف جاعوا أباهم عشاء يبكون، وهم لله ظالمون (').

لقد حاول "ثريح" من خلال استجلاب المثال التاريخي بناء واقع جديد، حيث انطلق من الحالة الفردية ليثيّ هذا الواقع، ويخرجه مخرج الحقيةــة الثابتة، وهذه الحقيقة تتمثل بأنّ ليس كل متظلم صادق في دعواه، وإن بـــا من حاله ما يدل على وقوع الظلم عليه، ومما يزيد هذا المثال قوة اتصــاله بالنص القر آني، وما له من دور كبير في حمـل المتلقـي علـــ الاقتهـــاع بأطروحة المنكلم.

ومن الحالات الخاصة المؤسبسة للواقع، القائمة على الاستدلال بالمثل؛ ما نجده في قصة "دغفل" مع "أبي بكر الصديق" - رضي الله عنه- في قصة المثل "إن البلاء موكل بالمنطق"، فقيها أن "أبابكر" صحب النبي -صــلى الله

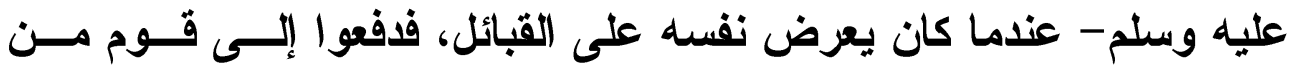
ربيعة، فسألهم "أبو بكر" عن نسبهم حتى أغضبهم، فقام منهم غلام يقال له: "دغقل" فقال له: يا هذا، إنك سألتنا فلم نكتمك شيئًا، فمن الرجل أنت؟، قال:

(1) ينظر : العقد الفريد، ابن عبد ربه الأندلسي، تحقيق: مفيد قميحسة، دار الكتـب العلميـة،

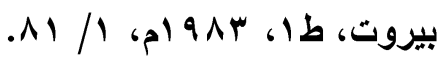

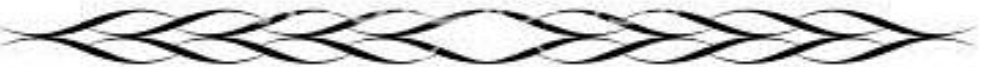




\section{الترقير الدولخ 2356-9050

رجل من قريش، قال: بخ بخ أهل الشرف والرياسة، فمن أي قريش أنـــ،

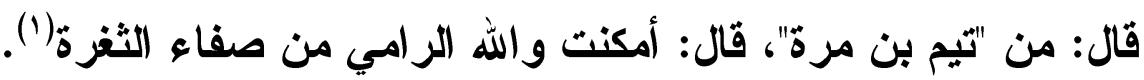
إن المتكلم يدعم حديثه وقوله بمثل يستدعيه " أمكنت الر امي من صفاء الثغرة" فينتقل من حالة خاصة إلى حالة خاصة أخرى؛ فهو يريد أن يوصسل لمخاطبه معنى تمكنه من الأمر، وسهولة الاتتصار على خصمه، ووضـوح عوره، ومكمن ضعفه، فربط ذلك بحالة خاصة أخرى هي: وضوح الثغزة من البعير للناحر، وهي اللهزمة التي يُنحر منها(؟)، وصفاؤها أي وسطها. وإن كان المثال يُؤتى به للبرهنة، ولتأسيس القاعدة، فإن هنــاك مـــا يسمى بالمثال التوضيحي، والأي يُر اد منـه تقوية الإذعان لقاعــــة معروفــة

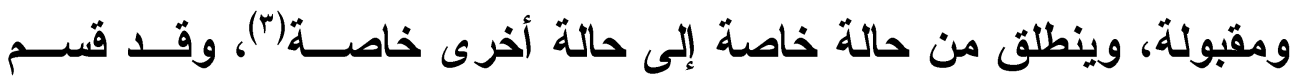
"أرسطو" أنواع الأمثلة التي يمكن أن تَرد في الخطاب إلــى نـــوعين: مثــال تاريخي، ومثال مخترع قائم على الحكاية المثليــة الــواردة علــى لســـان الحيوان، فَضرَْبُ المثنال يمكن أن يكون خياليًا، دوره ليس إثبات القاعدة بـلـل

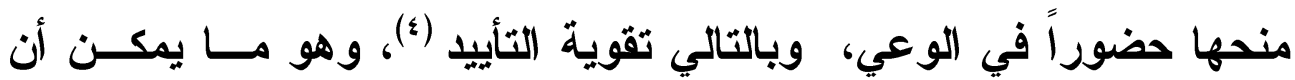
يُرج في إطار المثال التوضيحي، كما في قصة فخ الإسر ائيلي والعصفورة،

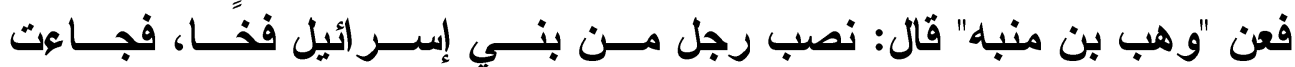

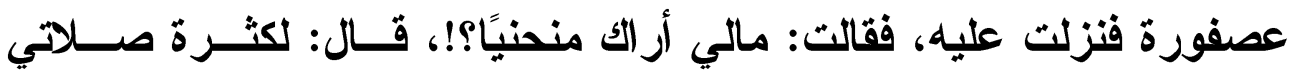

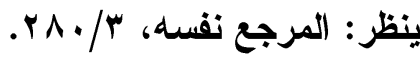

$$
\begin{aligned}
& \text { ينظر: لسان العرب، ه1/.9. }
\end{aligned}
$$

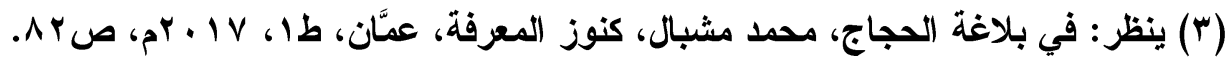

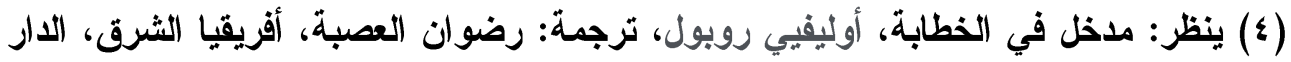




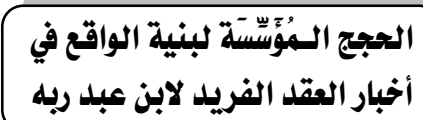

की 1 (1

العدد الخامس والعشروز للعام الr.rم العزام

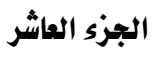

انحنيت، قالت: فمالي أرالك بادية عظامك؟!، قال: لكثرة صيامي بدت عظامي، قالت: فمالي أرى هذا الصوف عليك؟!، قال: لزهادتي فـي الـــنيا لبســـ الصوف، قالت: فما هذي العصا عندك؟!، قال: أتوكأ عليها، وأقضــي بهــا حوائجي، قالت: فما هذه الحبّة في يدك؟!، قال: قربان إن مرّ بــي مسـكين ناولته إياه، قالت: فإنتي مسكينة، قال: فخذيها، فدنت فقبضت على الحبّــة، فإذا الفخ في عنقها، فجعلت تقول: قعي قعي، لا غرّتي ناسك مسر اعِ بعـــك (أبد|(1)

لقد قامت هذه القصة على تحذير المرءع من الاغترار بالمظــاهر، وأن السلوك قد يكون على تباين مع المعتقد، فالقصة القائمة على المثال بمثابــة "قاعدة أخلاقية أو سلوكية يُتمثل بها في مواقف مشابهة، وكثيرًا ما يفصــح النص صر احة عن الغرض من ضرب المثل"(r)، كقول الراوي علــى لســان العصفورة: "لا غرنّي ناسك مراعِ أبدَا"، وقد عد "عبدالفتاح كليطو" التمثيـلـل على ألسنة الحيوانات أعظم الحيل التي صاغها الحكمـــاء للقيــام بــدورهم التعليمي، والتأثير على النقوس، ولألك فإنهم لا يخاطبون العقلاء فقط، وإنما يخاطبون السخفاء كذلاك، ولو كانوا لا يخاطبون إلا العقلاء لما احتاجوا إلـى

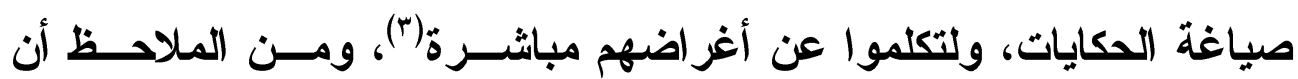

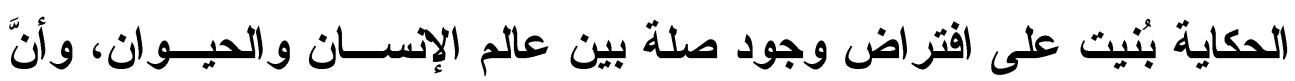

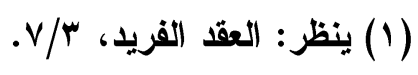

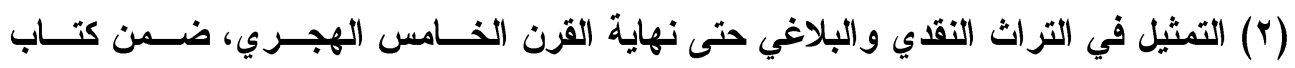

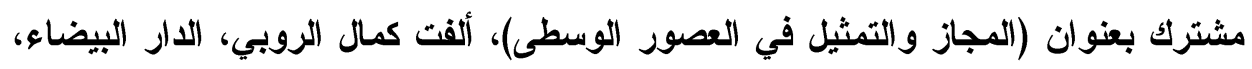

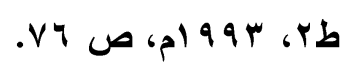

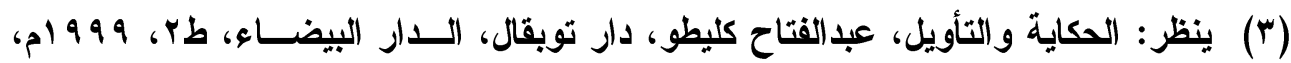

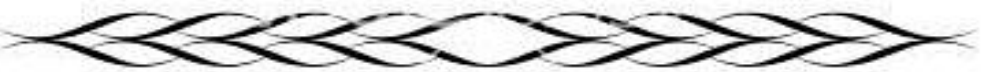


هناك تناغمًا مشتركًا يدركه السامع، حيث "تكمن خصوصية الحجاج المثلـي

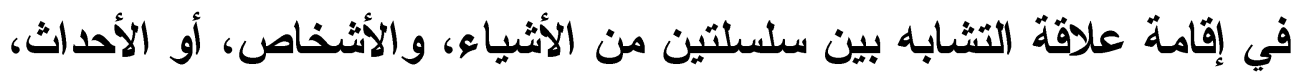

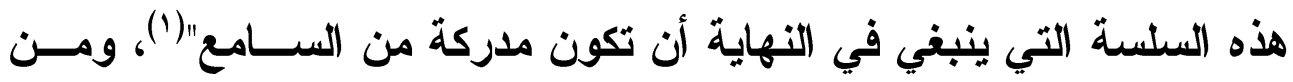

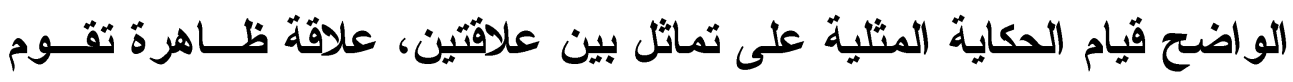

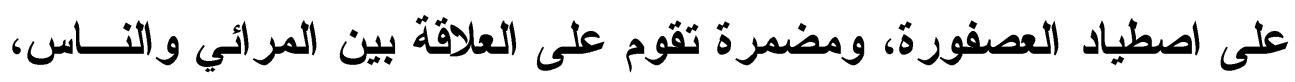

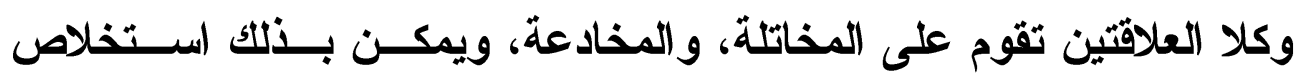

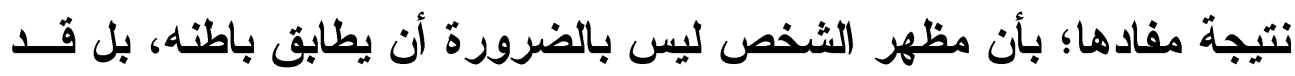

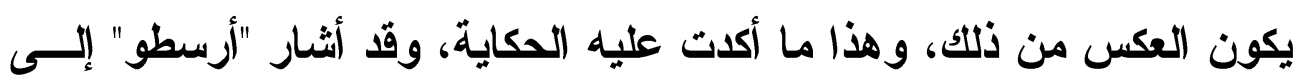

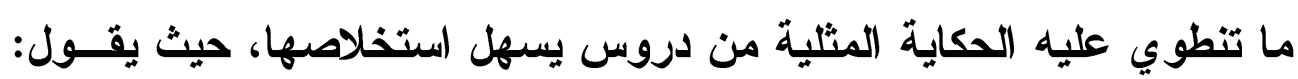

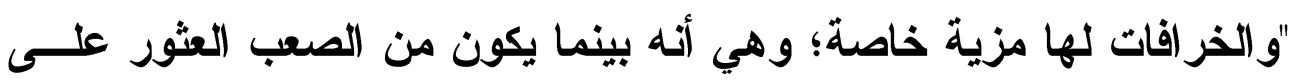

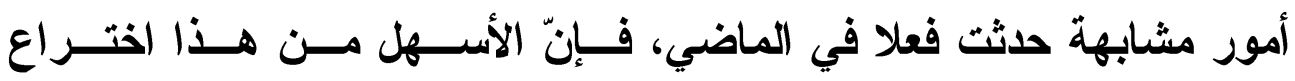

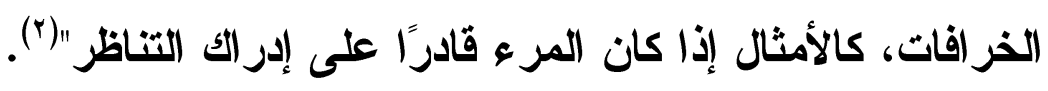
وقد يكون المثال التوضيحي مستمدًا من الوقائع التاريخية، ولقد أثثار

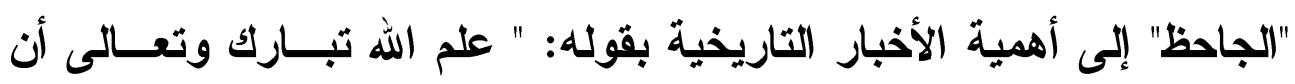

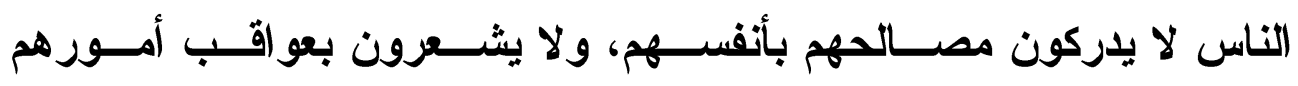

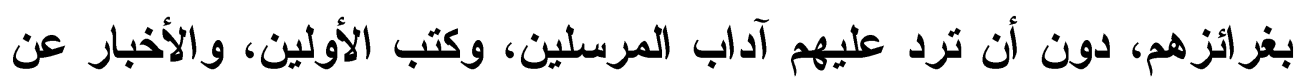

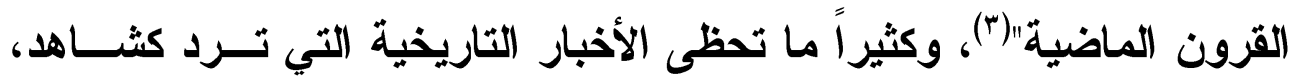

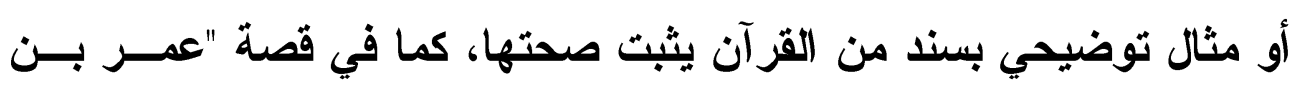

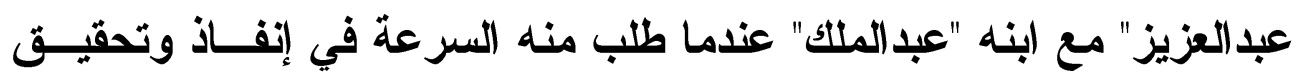

(1) في بلاغة الحجاج، محمد مشبال، ص الو، نقابًا عن جيل ديكلرك.

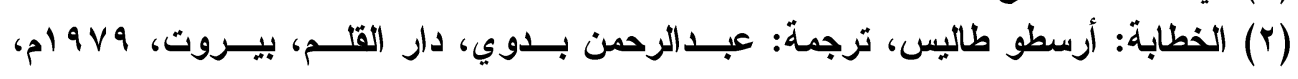
صاء ا.

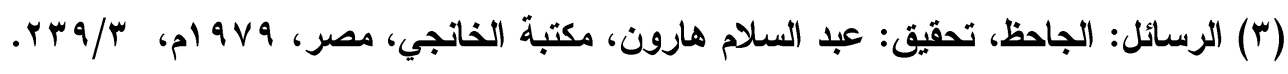




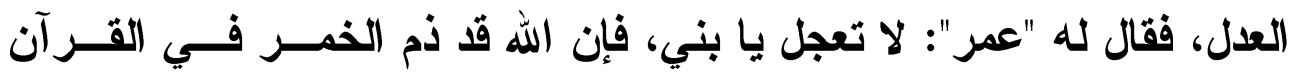
مرتين، وحرمها في الثالثة، وأنا أخاف أن أحمل الناس على الحــق جملــة فيدفعوه، وتكون فتنة(1)

لقد أراد "عمر بن عبدالعزيز" حمل ابنه "عبــــالملك" علــى الاقتتـــاع بتصرفه من خلال استجلاب مثال تاريخي متصل بالقر آن الكـــيم، باعتبـاره أثثد تأثيرًا، وأقوى في دفع المتلقي إلى الاقتناع، حيث تستحضــر الصــيغة

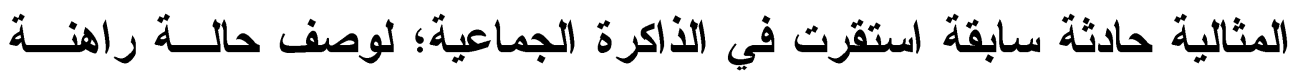
شبيهة في ظروفها، وملابساتها بالسابقة، إذ من شأن الاستناد إلى المتواتر المتداول المشهور أن يساهم في عملية الافناع، وأن يدعم عملية الحجاج(؟). ومن هذا القبيل خبر "هثام بن الحكم" مـع أحد خلقاء بنــي العبـــاس، حيث "قال رجل لبعض ولاة بني العباس: أنا أجعل "هثام بن الحكم" يقول في

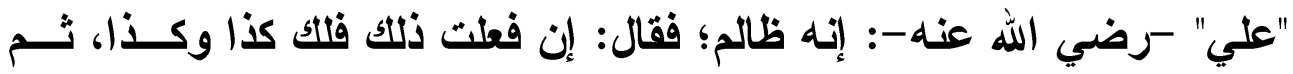
أُحضر "هشام"، فقال له: نشدتك الله "أبا محمد"، تعلم أن "علياً" نازع "العباس"

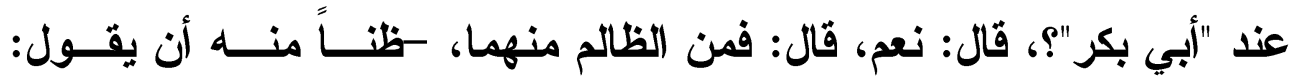

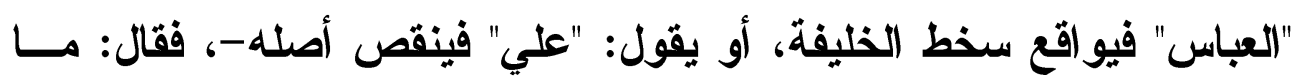
منهما ظالم، قال: فكيف يتنازع اثنان في شيء لا يكون أحدهما ظالمــا، قال: قا تنازع الملكان عند "داود" -عليه السلام - وما فيهما ظالم، ولكن لينبهــا "داود" على الخطيئة، وكذلك هذان أرادا تتبيه "أبي بكر" على خطيئته، فُأُسكت الرجل، وأمر الخليفة لــ"هشام" بصلة عظيمة"("). (Y) ينظر : الحجاج في الشعر العربي، سامية الدريدي، عالم الكتب الحديث، إربد، الأردن، طץ،

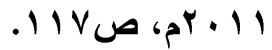

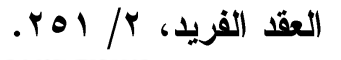

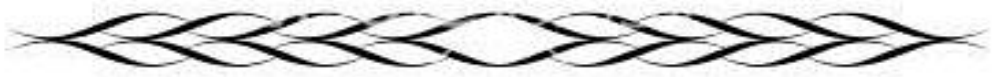


لقد اسنطاع "الحكم بن هشام" إقناع الخلفية بأن الخلاف الذي وقع بين "علي" -رضي الله عنه- وعمه "العباس" لا يستلزم أن يكون أحدهما ظالماً،

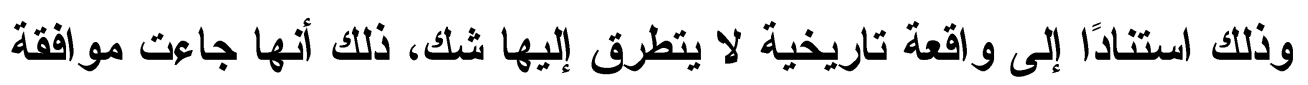

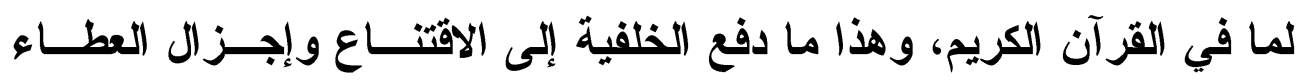

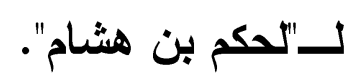

ومن هذه الثواهد قصة "خالد القسري" عندما أمسـره الخليفــة بثــتم الحجاج، فقد "صعد "خالد القسري" المنبر يوم جمعة، وهو والي مكة، فــذكر فئه

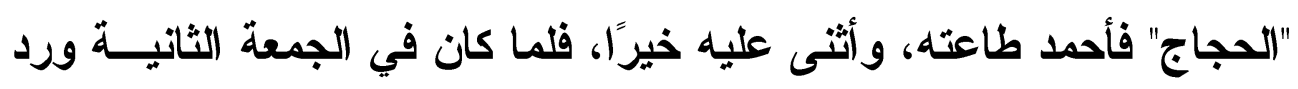

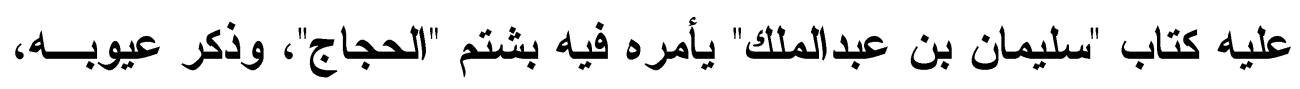

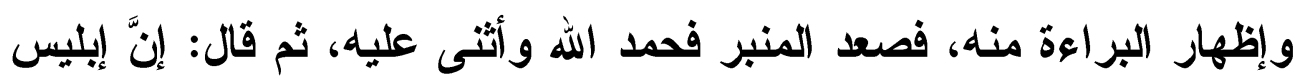

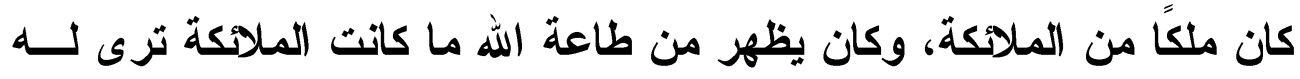

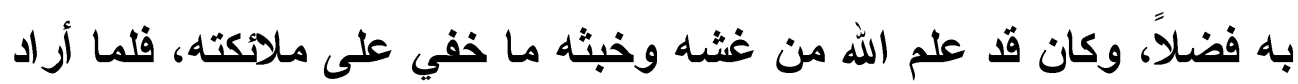

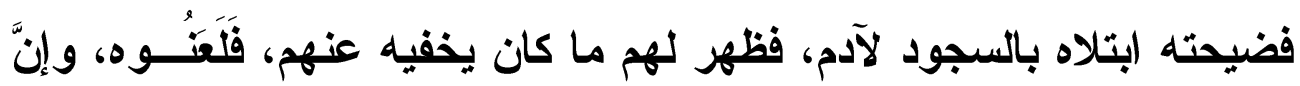

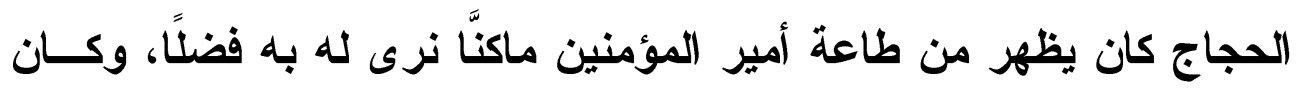

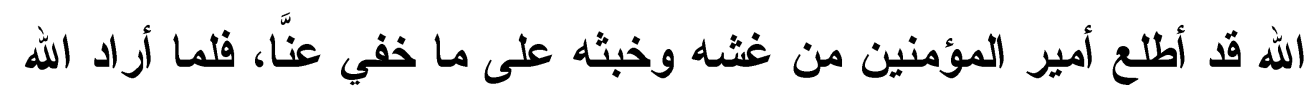

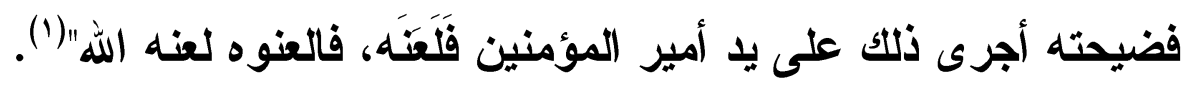
لقد استند "خالد القسري" في ذمه لــ"حجاج" بعد الثناء عليه على مثال

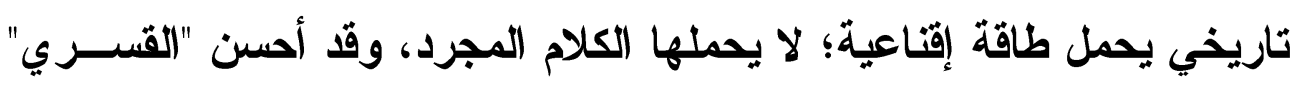

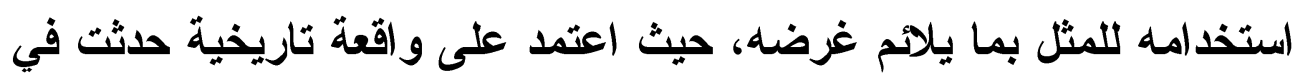

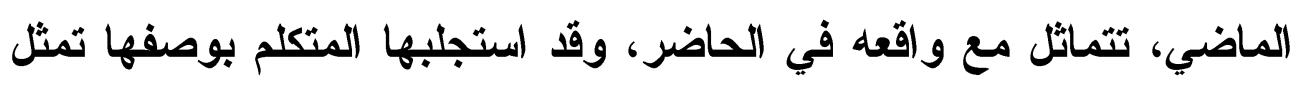




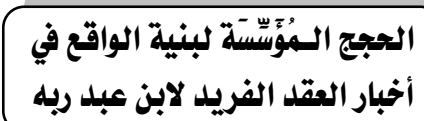

?

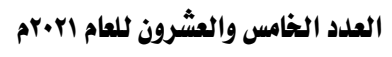

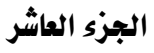

قيمة حجاجية تفرض سلطتها على المخاطَب؛ لما تحدثه لايه من اســتجابات تثتوافق مع مقاصد المتكلم ومواقفه. من هنا يصـح القول إن وظيفـــة المثــلـ وظليفة برهانية تعتمد على القياس الاستدلالمي من أجل التــأثير، والإقتــاع،

و التسليم، وليس مجرد شاهد بياني وتوضيحي ('). ومن شواهد الاستدلال بالمثل أنه لما قُتل "عمار بن ياسر" في صفين، وقد أخبر النبي -صلى الله عليه وسلم - بأنه ستقتله الفئــة الباغيــة، قــال

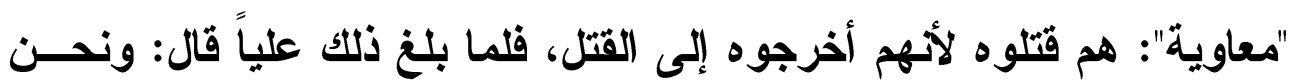
قتلنا حمزة لأنتا أخرجناه(r).

لقد قام "علي" -رضي الله عنه- بلاعم حديثه بمثال تاريخي اســتلدعاه لينتقل من حالة خاصة إلى حالة أخرى، فقد أر اد أن يُظهــر تهافــــــــام "معاوية"، ومكمن ضعفه، فربط ذلك بحالة خاصة أخرى وهي خروج "حمزة

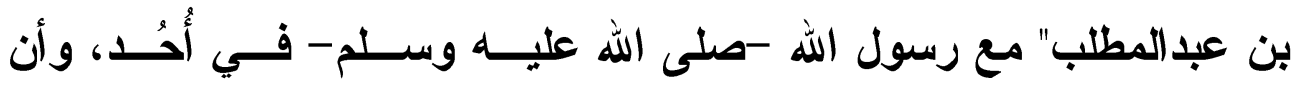

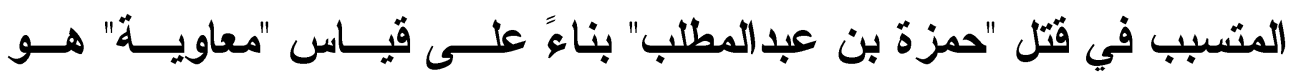
الرسول -صلى الله عليه وسلم- وأصحابه؛ لأهمم أخرجوه إلى القتال، وذلك لا يقره عقل ولا دين، لنصل بذلك بأن حجة "معاوية" بأن علياً وأصحابه هم

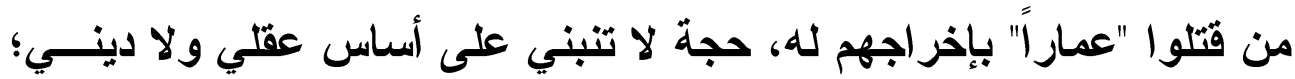
وذلك باستناده على شاهد تاريخي متأكد غير مجادل فيه.

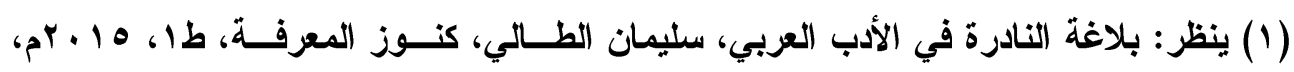
صצr

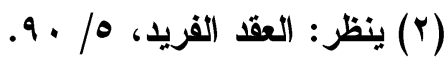




\section{r- المبحث الثاني: المجاج بالصور البلاغية:}

إذا كان الحجاج يمر عبر تقنيات متعددة فإن الصورة البلاغية تعد من

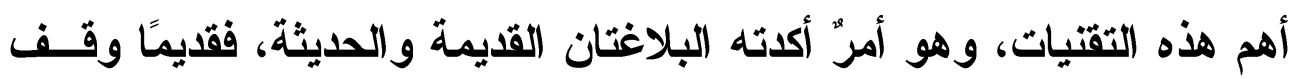

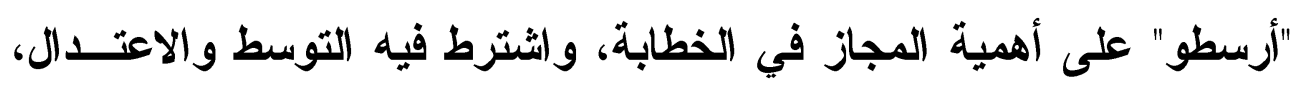

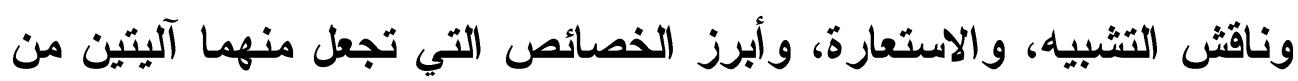

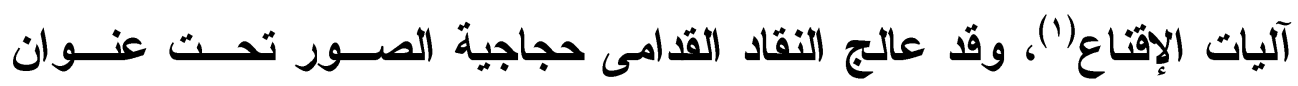

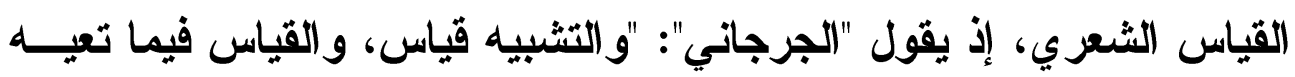

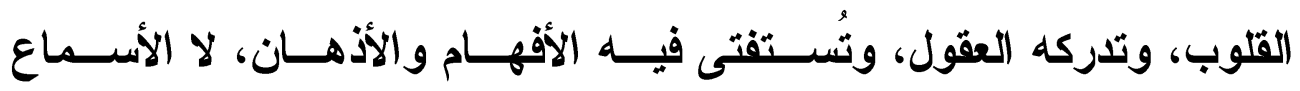

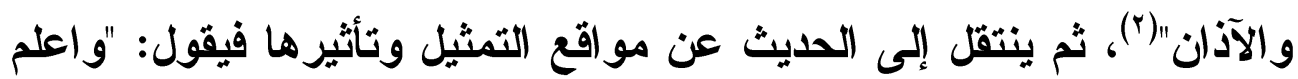

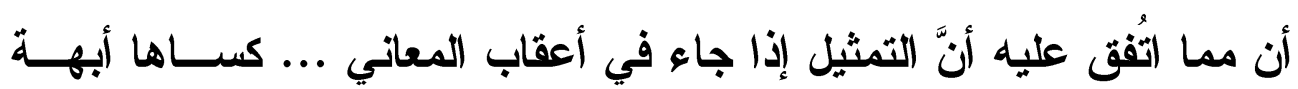

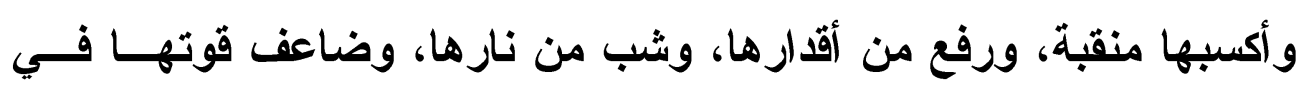

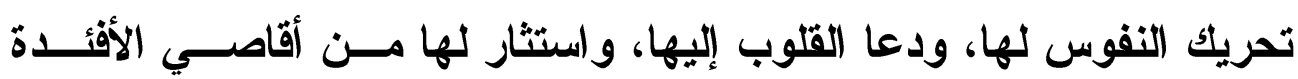

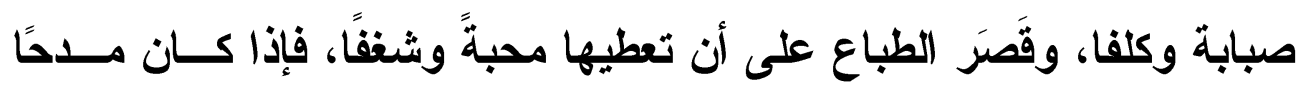

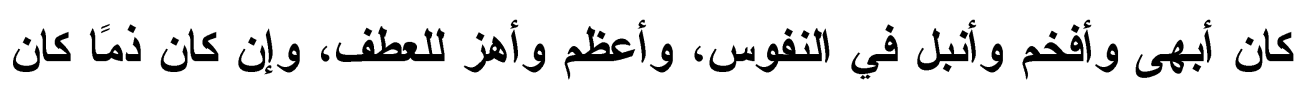

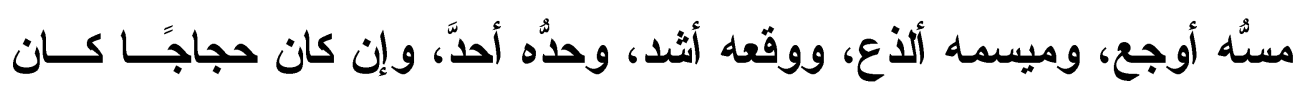

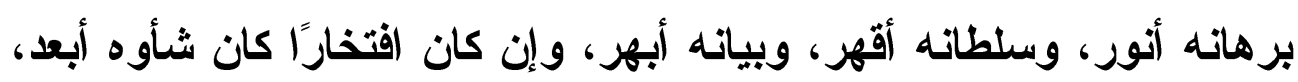

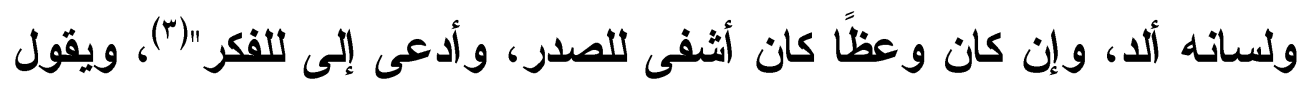

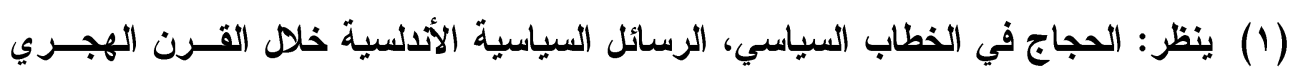

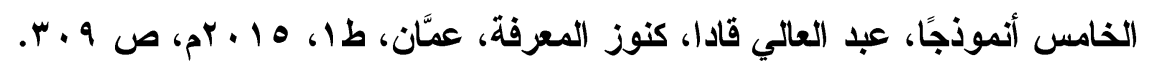

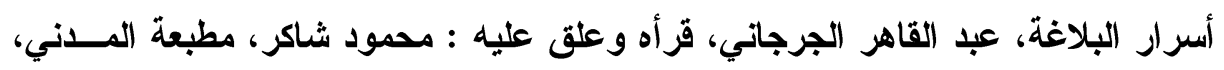

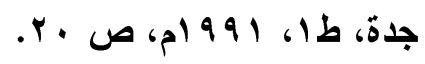

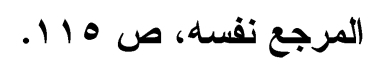




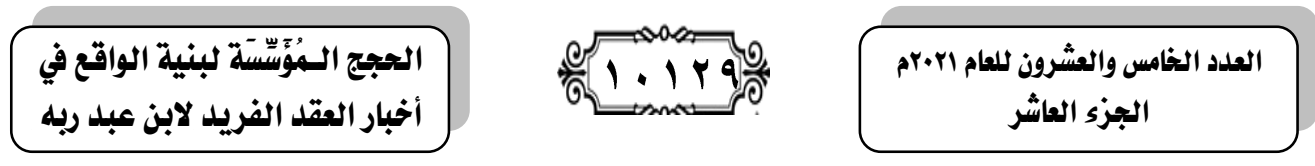

في موضع آخر في معرض حديثه عن أثر الصورة " تُكسب الانيء رفعـة،

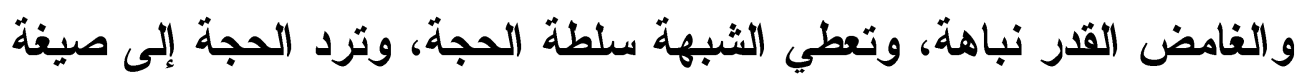

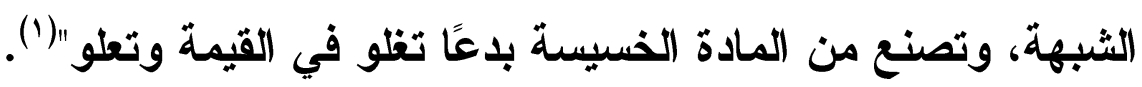
ويرى "بيرلمان" و"تيتيكا" أنَّ التمثيل في الحجاج ينبفي أن تكــون لــهـ

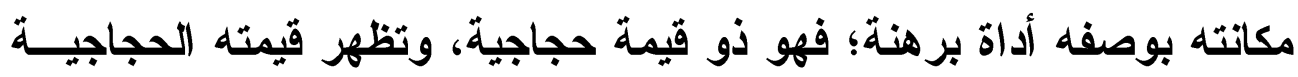

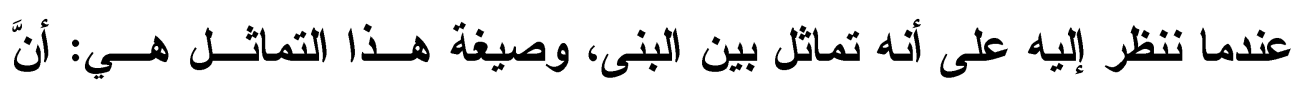

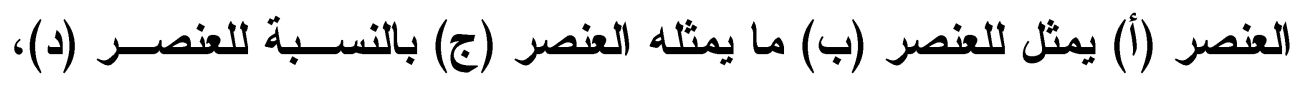

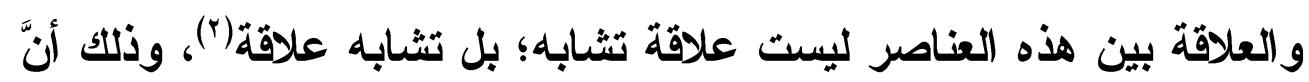

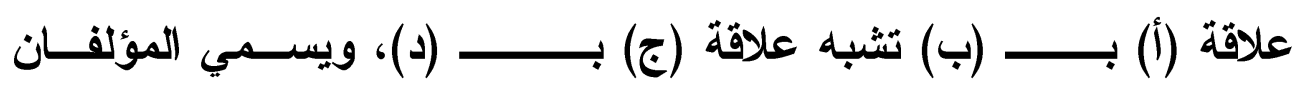

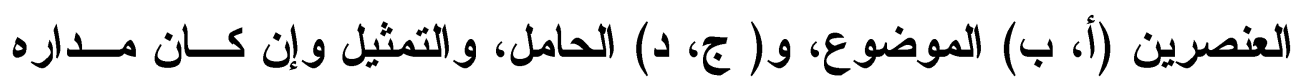

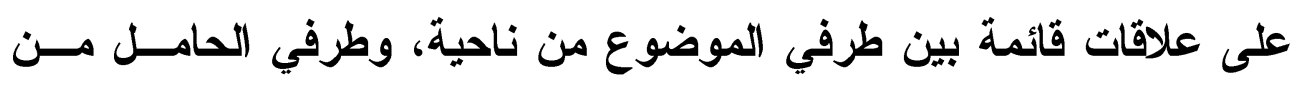

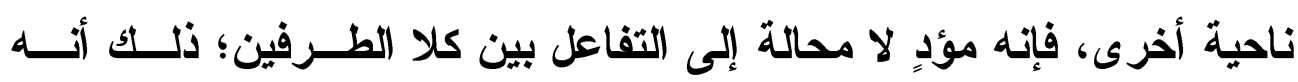

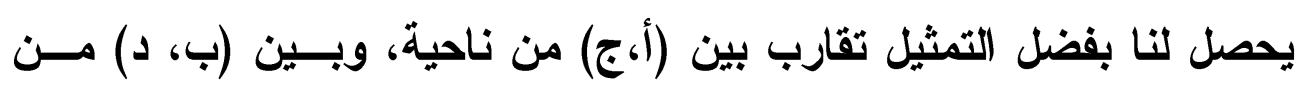

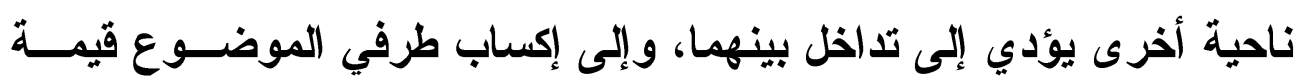

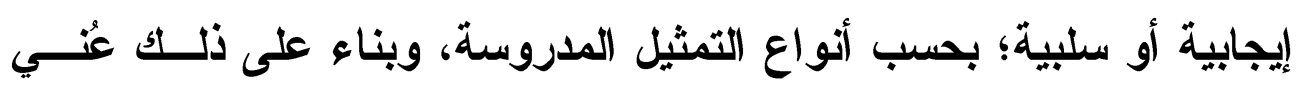

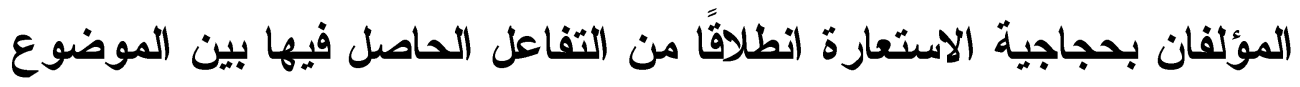

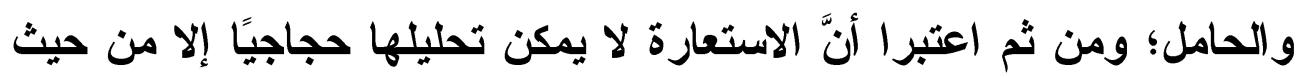

(1) أسرار البلاغة، عبد القاهر الجرجاني ، ص ب ع س.

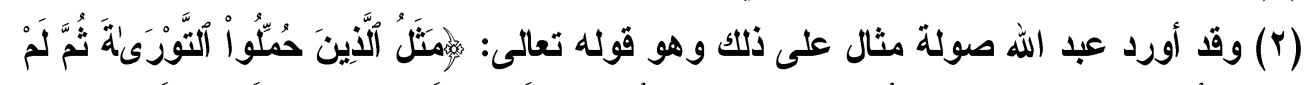

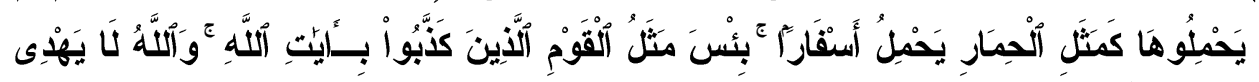

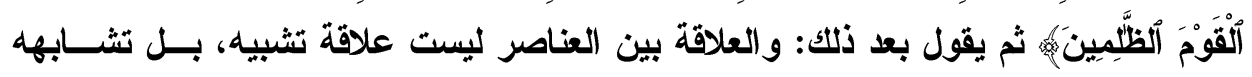

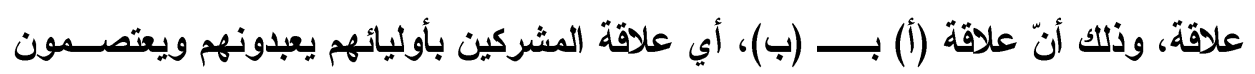

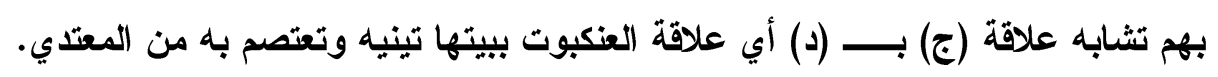


هي تمثيل مكثف موجز، ووجه الكثافة فيه، والإيجاز الآدماج الحاصل بـين أحد عناصر الموضوع وأحد عناصر الحامل اندماجًا لا يمكن معه معرفة أي العنصرين هو الموضوع، وأيهما الحامل('). وقد خلص "عبدالله صولة" من حجاجية الصورة إلى أنّ مدار الحجـــاج فيها على المحل الشاغر، ويقصد بذلك الجزء الضمني من الخطاب، يقــول: "ومما يؤيد قولنا بأن هذا المحل الثاغر هو بؤزة الحجاج، وبقــاؤه ضــمنيًا

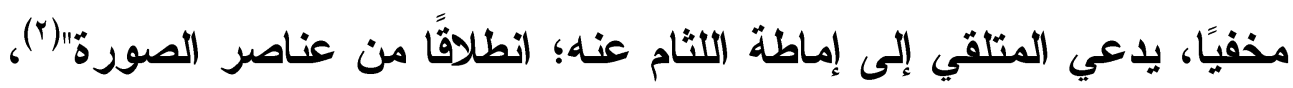

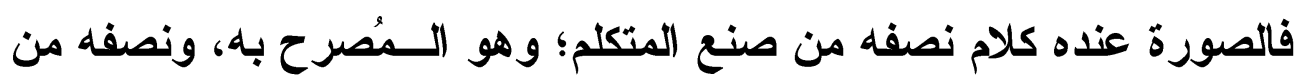
صنع المتلقي؛ وهو الضمني "وهذا الوضع هو الأي يكقل للصــورة قـــــها

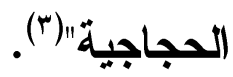

وتتعدد الغايات الحجاجية في الصور البلاغية، فقد يعمد المــتكلم إلـى التثبيه لتوضيح المعنى، وتثبيته في ذهن المتلقي، كما في قصة زياد العتكي

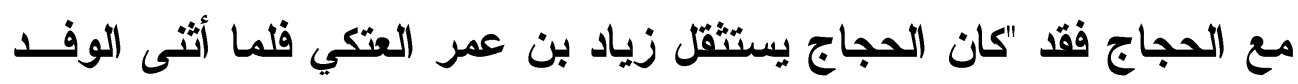

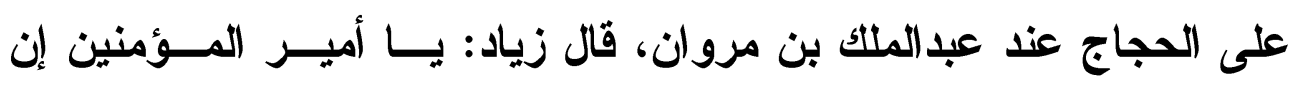
الحجاج سيفك الذي لا ينبو، وسهمك الأي لا يطيش، وخادمك الذي لا تأخذه فيك لومة لامث، فلم يكن بعد ذلك عند الحجاج أخف، ولا أحب إليه منه"(؛). لقد أر اد "العتكي" أن يكشف لــ"عبد الملك" عــن شــجاعة "الحجـــاج"، وصدق ولائه، ولإثبات حقيقة الاعوى للمتلقي؛ انتزع مــن عــالم الخطــاب

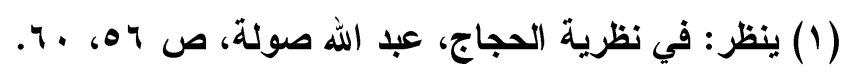

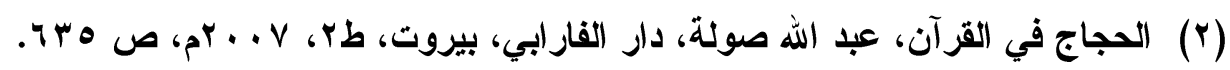

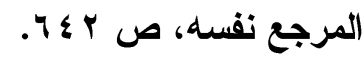

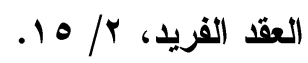

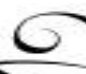




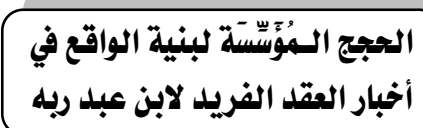

?

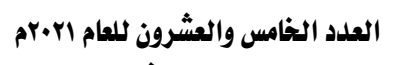

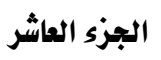

المشترك والمتفق عليه صورثين، يعرفهما الجميــع بــالحس، والمشــاهدة، وهما: صورة السيف الصقيل، والسهم الصــائب الــــي لا يطــيش، وهمـــا صورتان محسوستان، تقربان المعنى، وتجليانه للمتلقي، وتشــاهمان فـي إقناع المتلقي بحقيقة الاعوى، فالعرب القدماء يهتمون بالصورة، من خلال

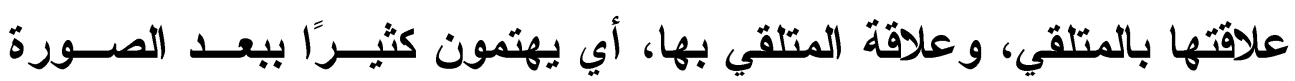
الحجاجي، من حيث هي تأثير في الوجدان، وإقناع بالفكر (1). ولقد قامت الصورة في هذا الشـاهد على التشبيه البليغ العـاري مـن وجه الشبه، "فيكون عدم ذكر هذا الركن مدعاة إلى أن يُعمِل المتلقي كفايتــهـ الثقافية والمنطقية؛ لتبيين المسار الحجاجي في التشبيه"(؟). لقد أدى التشبيه البليغ دورًا كبيرًا في تأدية المعنى، وتوضيحه لإقتاع المتلقي به، حيث جعل المتكلم من المعقول محسوسًا "ومعلوم أن العلم الأول

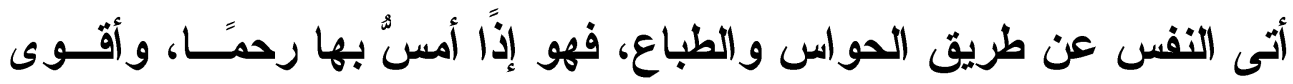
لايها ذممًا، وأقدم لها صحبة، وآكد عندها حرمة" (بات. فالصورة كما تُضمر مدحًا لــ"لحجاج" فإنها كذلك تُضمر مدحًا لـــــــابـ الملك بن مروان"، فالسيف يستمد قوته من الساعد الأي يحملـــه، والســـم تتمكن إصابته من خلا اليد التي تتبله، لقد استطاعت الصورة أن تثير فـي تفس المتلقي كوامن الإعجاب والسرور، وتدفعه إلى تغييز سلوكه ومعتقــــه

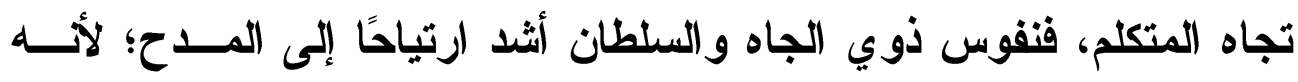
يُرضي إحساسًا بالعظمة تنميه السلطة في القلب، فإذا ما تمكن المتكلم مــن

(1) ينظر: الحجاج في القرآن، عبدالله صولة، صالم ؛ .

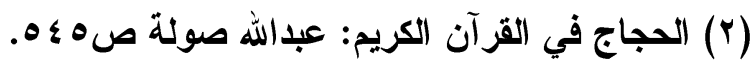

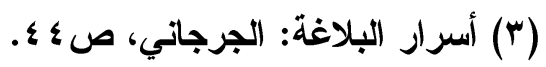


تحريك هذا الإحساس في قلوب أهل السلطان، بصورة فنية مؤثرة ومثيــرة،

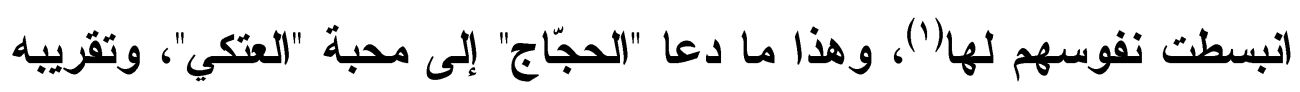

وإلى جانب التثبيه البليغ نجد التشبيه المرسل، الذي يقوم على توافر

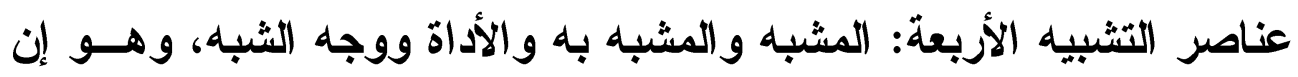
كان أقل فاعلية في تجسيد أبعاد الصورة الحجاجية، كما يتبين ذلك من خلا لإله

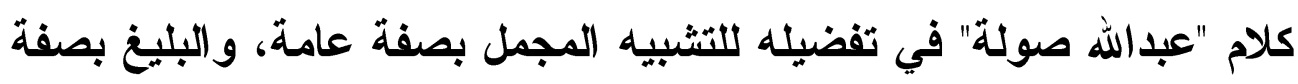

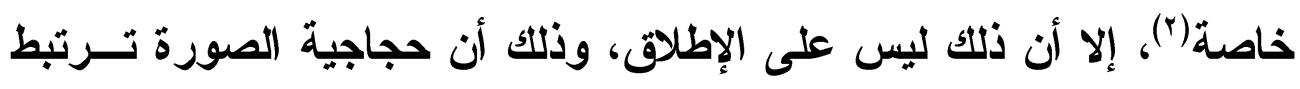

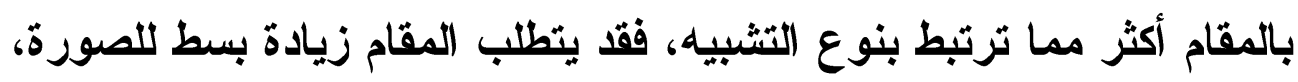

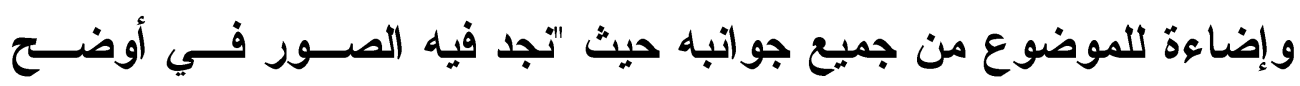

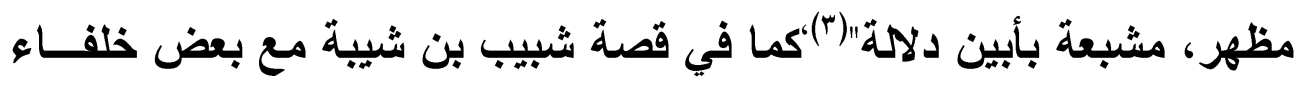

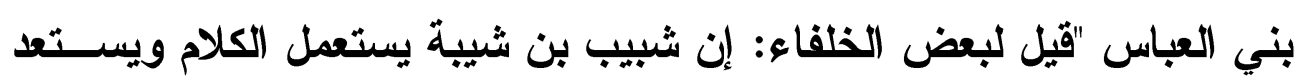

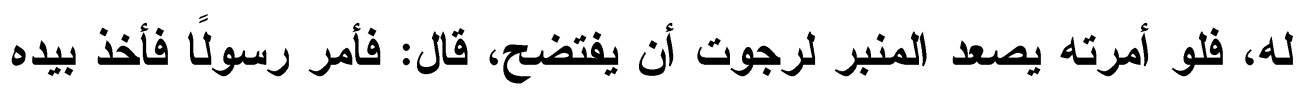

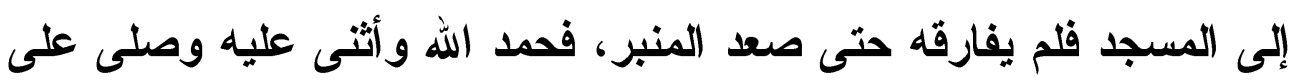
النبي -صلى الله عليه وسلم- ثم قال: ألا إن لأمير المؤمنين أثثباهًا أربعة :

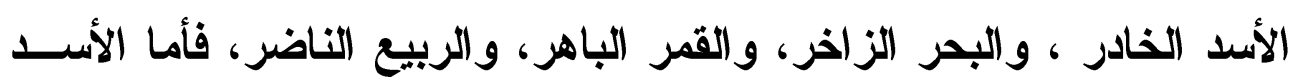

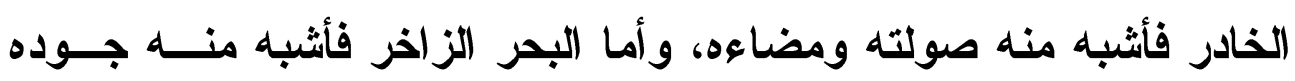

(1) ينظر : الحجاج في الخطاب السياسي الرسائل السياسية الألدلسية خــله القــرن الهجـري

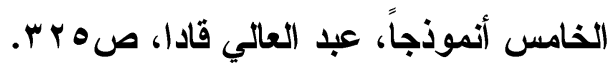

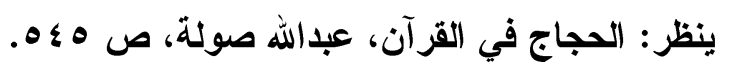

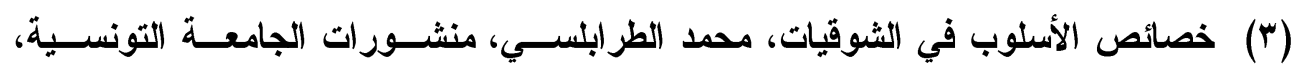

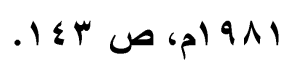




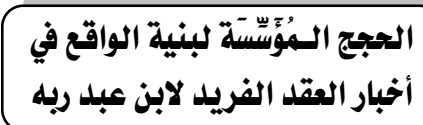

की

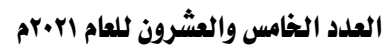

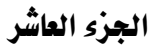

وعطاءه، وأما القمر الباهر فأشببه منه نوره وضياءه، وأما الربيع الناضــر

فأشبه منه حسنه ويهاءه" (1)

لقد جاء التثبيه في هذا الخبر مرسيًا، حيث وجد فيه "ثــبيب" خيـر

وسيلة لبسط صفات الممدوح في أبهى حلة، والتأكيد عليها، فالمقام يتطاـب هذا النوع من التشبيه، الأي تبرز فيه الصورة بأوضح مظهر وأقوى دلالة، فالخطاب يقوم علــى تقريسـب الصــورة باســتعمال المعـاتي المشــهورة، والفضاءات القريبة من عالم الـــُخَاطَب الحسي (r). فالمعاني الغامضة قد لا تتناسب مع المقام، فالمقام مقام مدح يحتــاج إلى وضوح وبيان، والجمهور المـخاطَب جمهور بسيط يحتاج إلـى صـــور قريبة، ومعان مشهورة، وهو ما يُعبر عنه بــ"العقد الذي تُبنى عليه معـاني

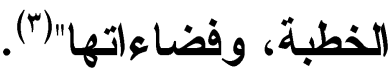

وهو كما أثنار هثام الريفي "وضع للقول ثقافي، وليس وضعًا (كتسبه

من خصيصة داخليه فيه"(๕).

وفي موضع مختف نقرأ استخدامًا آخر لهذه الحجة من خلال التشبيه البليغ، وذلك في قول ابن هبيزة لأبي جعفر المنصــور" "إنّ أمسـارتكم بكـر فأذيقوا الناس حلاوتها وجنبوهم مرارتها"(ه)

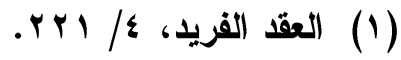

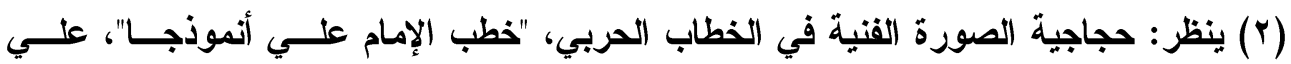

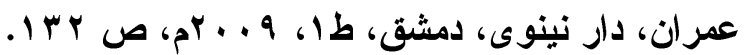

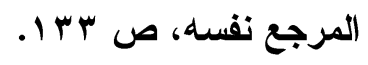

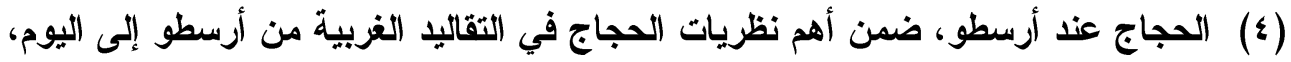

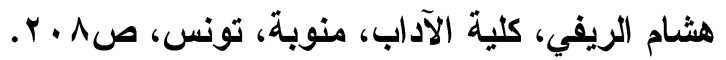

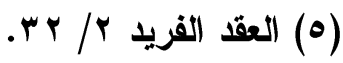


إن الحِجاج في هذا الثناهد يكمن في تثبيد واقع جديد، وشد المتلةـي إليه، واستمالته لقبوله، ويمكن تبيّن ذلك من خلال رد الصورة إلى مقدمتين

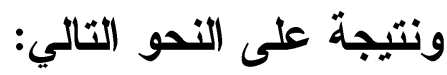

\begin{tabular}{|c|c|}
\hline أمارتكم بكر & مقدمة صغرى \\
\hline البكر هي محط الأظظار وعليها تُعقد الآمال & مقدمة كبرى \\
\hline 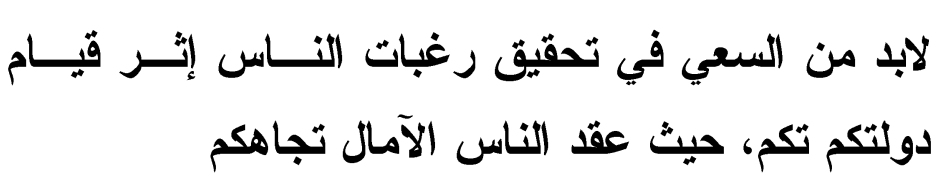 & نتيجة \\
\hline
\end{tabular}

لقد أضمر القياس المقدمة الكبرى والنتيجة، وأظهر المقدمة الصــغرى

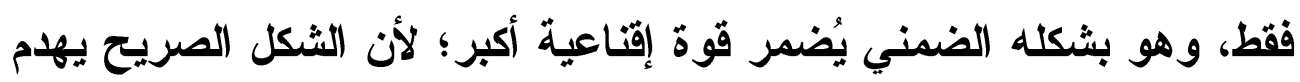

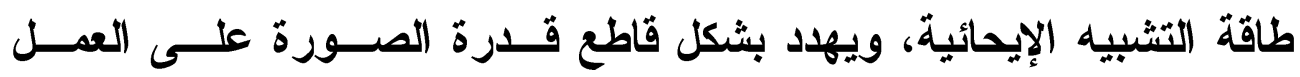

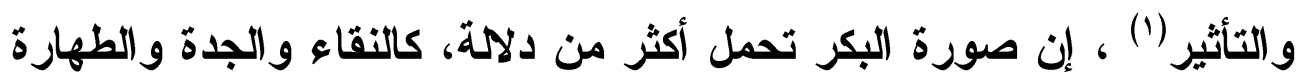

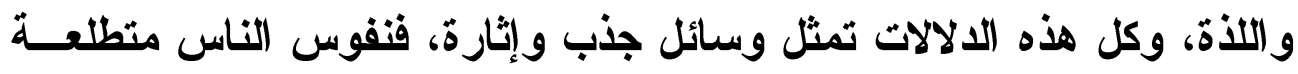

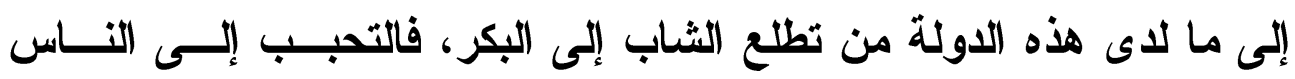

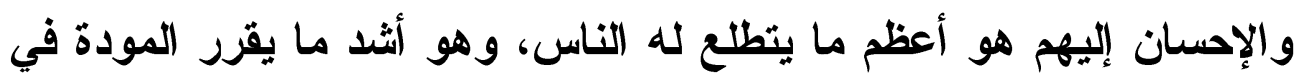
قلوبهم ويؤكدها.

وقد يلجأ المتكلم إلى التمثيل لتقريب المعنى، وتثبيته في ذهن المتلقي، كما في قصة "أبي قلابة" عندما طُب لقضاء البصرة فهرب إلى الثام، فقابل 
"أيوب السختياني"، فقال له: لو أنك قبلت القضاء وعدلت كان لــك أجــران، قال: يا أيوب إذا وقع السابح في البحر فكم عسى أن يسبح('). لقد اضطلعت الصورة بوظيفة تقريب المعنى وتوضيحه؛ بارتكازها على عالم الخطاب حيث يمثل منطلقًا مشتركًا يصل المتكلم بالمتلقي، وهو ما بحثّه "عبدالله صولة" في إطار الأبعاد الحجاجية لمادة الصورة في القرآن الكــريم، وخلص إلى أن كل الصور في القرآن لها مـــادة معلومـــة لــــ المتلقــين، مأخوذة من عالم خطابهم، ومألوفة لايهم، ومرتبطة عندهم بلالاة معينة(؟). وتكمن النجاعة الحجاجية لهذا التصوير في استنادها إلى أمور لا يسـتطيع المتلقي إنكار ها؛ لاتتمائها إلى العالم الحسي المشاهد، حيث استمد "أبو قلابة" صورة البحر كمادة يدعم بها حجته، فالبحر يحظى بموافقة طرفي الخطــاب

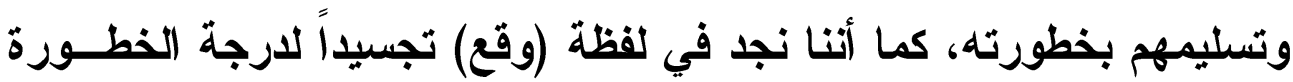
العالية، بما تحمله من حيرة واضطر اب وانعدام القدرة على التحكم بــالنفس والسيطرة عليها، لألك فإن الحضور المشاهد لوجه الشبه بين البحر المستثل إلى العالم الحسي وتقلا القضاء يُمكَّن المعنى في نفس المتلقــي، ويضــمن درجة أعلى في إقناعه.

ومن الثواهد على التمثيل قصة "المنصور" مع "جعفـر بــن محمـــ"، وذللك أنّ المنصور لــــــا حج في إحدى الســنوات مــرّ بالمدينــة، فقــال

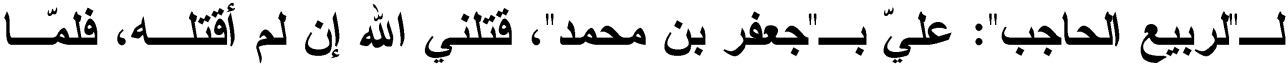
أتوه بـه، قال: يـا عدو الله تعمل عليّ الغوائل في ملكي، قال "جعفر": يـا أميــر

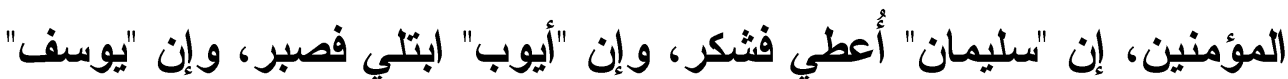




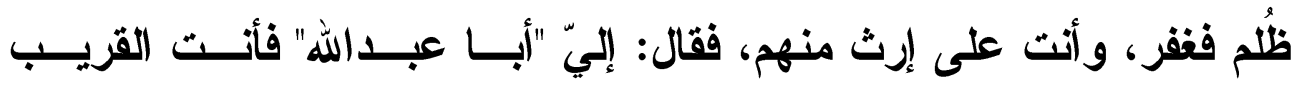
القرابة، ثم صافحه، وأجلسه معه على فر اثشه، وقال لحاجبه: عجل بكســوته

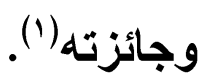

لقد حاول المتكلم أن يقيم علاقة تشابه وتماثل بين المشبه "أبو جعفـر المنصور" والمشبه به الأنبياء الأين وردت أسماؤهم في الخبر، وهذا التماثل

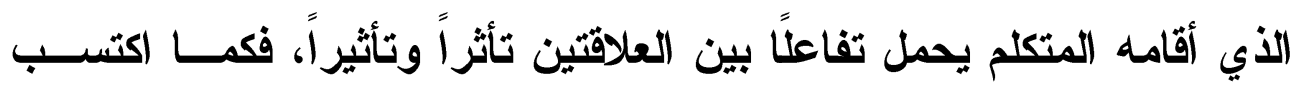
الأبياء (سليمان، أيوب، يوسف) قيماً ايجابية أصبحت بمثابة المــثل التـي

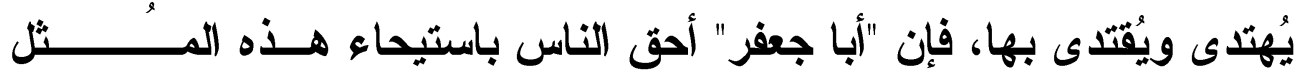
والتأثر بها، فهو ملك وتعرض لثورات كادت تعصف بملكه، وله بمن ســاف من الأبياء أسوة حسنة، لقد حاول المتكلم من خلال إقامة علاقة التثــابه، إنشاء واقع آخر لإقناع المخاطب، واستمالته إلى العفو والصفح. إن المقصد من التمثيل تقوية الشعور لاى المخاطـب بحضــور هـذـه

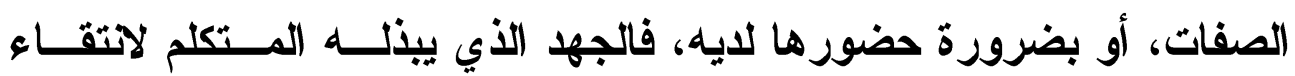
الصورة وربطها بالمعنى المقصود يجب ألا يقتصر على المقاصد الجماليـة فقط، وإنما يجب أن يتوافق ذلك مع غايات حجاجية يسعى المتكلم من خلالها إلى التأثنر في المتلقي، واستجلاب انتباهه؛ لأنه يستدعي خبر اته ومعارفــه، وكلما كان التداخل بين طرفي التشبيه قويًا صار أدعى للتأثنير، وأكثر فعالية في أداء المعاني "فمأتى الحجاج في التثبيه الضمني أنه فياس خطابي بنّـي

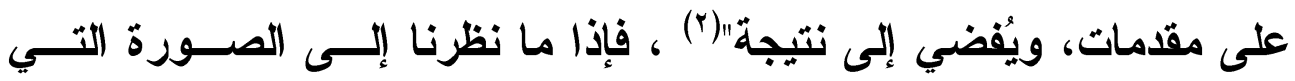

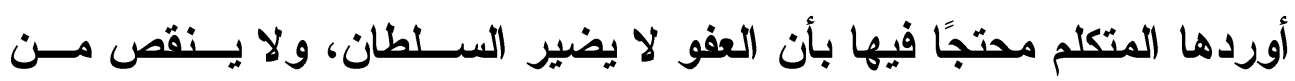




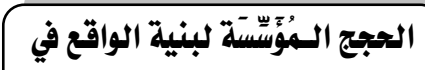 أخبار العقد الفريل لابن عبل ربله}

مكانته، وقفنا على الطاقة الحجاجية الكامنة في التمثيل، حيث يمكن أن نُرجع احتجاج المتكلم إلى مقدمة صغرى ومقدمة كبرى ونتيجة. مقدمة صغزى | المنصور تنثابه حالته مع حالة مَن سبق من أنبياء مقدمة كبرى كل علاقة تشابه تقوم على التأثر والتأثير المنصور أحق الناس بالتأثز بمن سلف مــن الأثبيــاء وأخذ أحسن ما لايههم من صفات وقيم

ومن الثواهد القائمة على التمثيل قول عمر بن ذر لأبيه: "ما لــــ إذا تكلمت أبكيت الناس فإذا تكلم غيرك لم يبكهم، قال: يا بني، ليســت النائحسـة (الثكلى كالنائحة المستأجرة" (1)

لقد استثد المتكلم إلى حجة التمثيل؛ لإثبات وجهة نظـــره مسـن خــله معطى محسوس، وطاقته الإقناعية لا تستند إلى الحس فقط "و إنما لأن هـــا الحس نفسه منتزع من تجارب المتلقين وممارساتهم المعيشية ومشاهداتهم

$$
\text { (العينية، ومن سلوكهم اليومي"(r). }
$$

لقد أقام المتكلم صورتهـ الحجاجية على قياس أضـــر فيــه المقدمــة الكبرى والنتيجة وأظهر المقدمة الصغرى فجاعت كالتالي:

\begin{tabular}{|c|c|}
\hline ليست النائحة الثكلى كالنائحة المستأجرة & مقدمة صغرى \\
\hline مظهر الحزن لا يدل على حقيقة الألم والفاجعة & مقدمة كبرى \\
\hline مظاهر الناس وإن كشفت عن الزهد والورع لا تدل على & نتيجة \\
\hline
\end{tabular}




\section{الترقير الدولخ 2356-9050

لقد حاول المتكلم من خلال هذا التمثيل المادي المحسوس دفع المتلقي

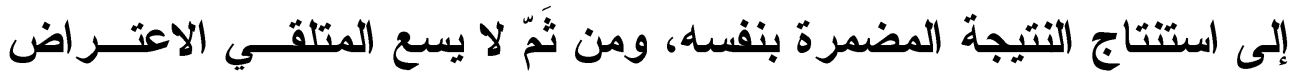

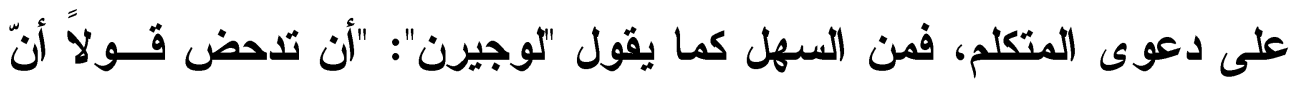

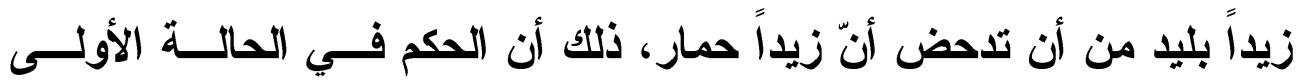

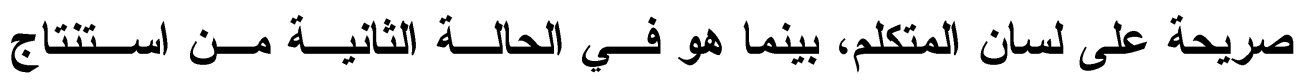

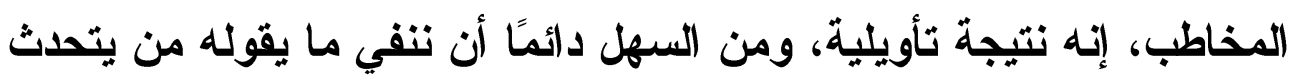

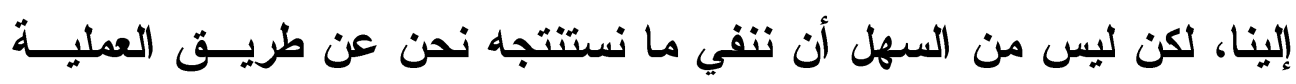

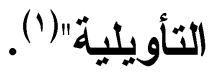

ومن شواهد التمثيل ما ورد أنّ داود بن علي خطب في مكــة وقـــال:

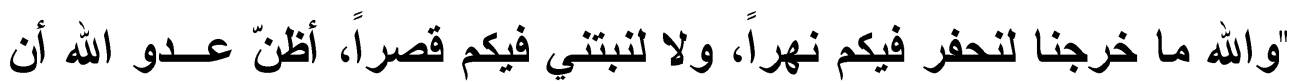

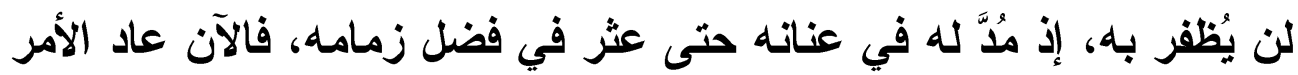

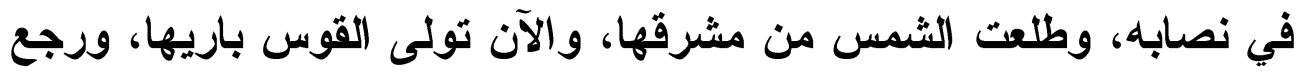

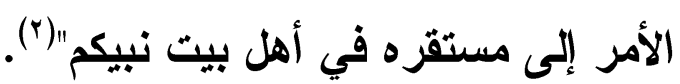
لقد أقام "داود بن علي" دعوى مفادها أن الخلافة آلـــ إلـى أهلهـ

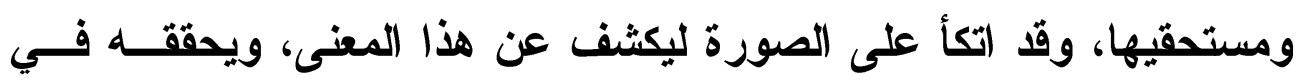

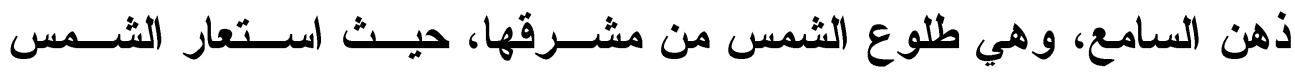

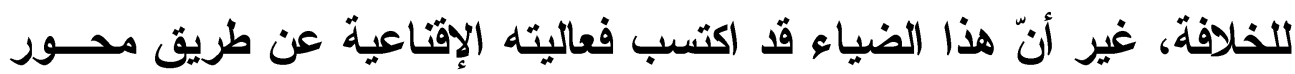

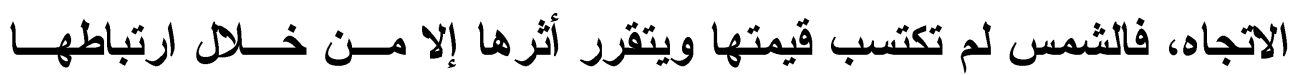

(1) الاستعارة والحجاج، ميشيل لوجيرن، تعريب: الطاهر وعزيز، ضمن مجلة المناظرة، العدد

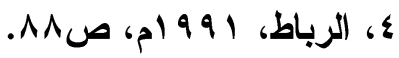

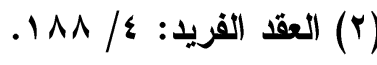




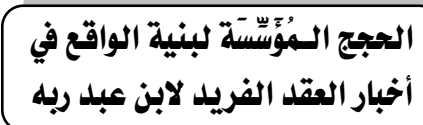

?

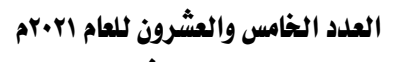

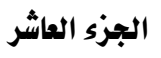

بالجهة والمسار التي خرجت منه، فهي بذلك "تُعبِّر عن موضــع ذي قيمسـة

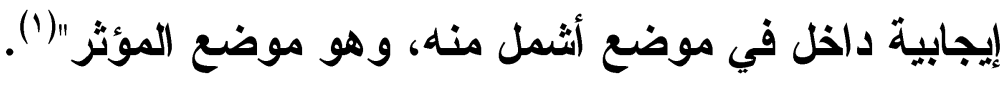

إن المتكلم يريد أن يثبت عبر عملية الاستدلال بالصورة إثبات دعوى، وهي أحقية بني العباس بالخلافة، فدعوى الإثبات بالكلام المجرد قابل للإنكار

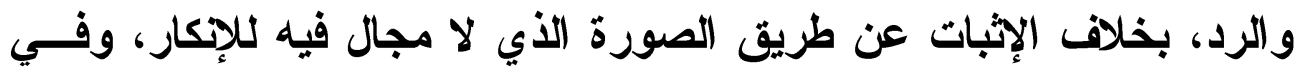

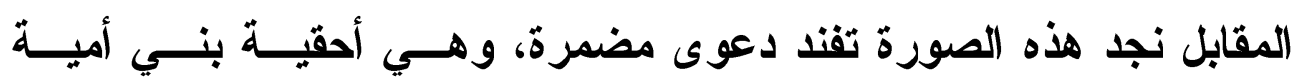

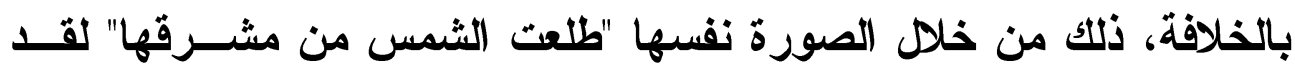

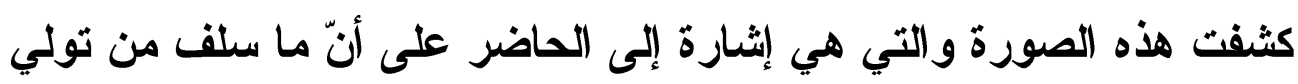

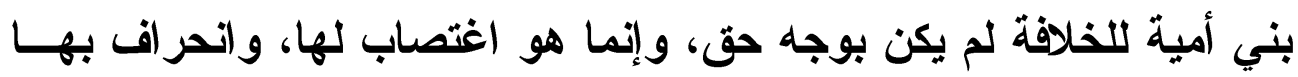
عن مسار ها الحقيقي.

إنّ القيمة الإيجابية التي تحملها هذه الصورة لم تأتِ من إسناد ظهور

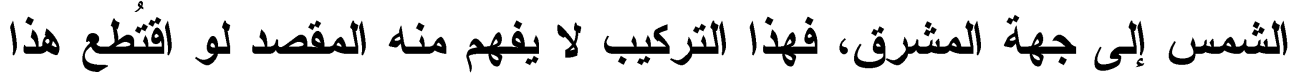

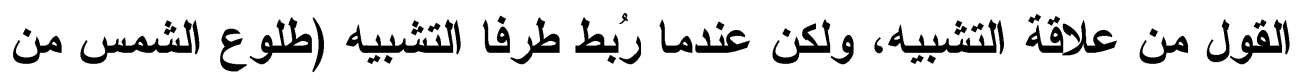

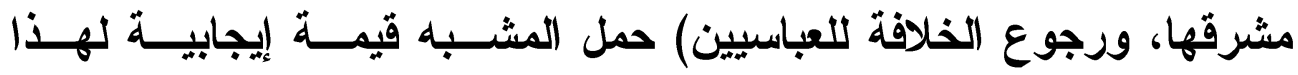

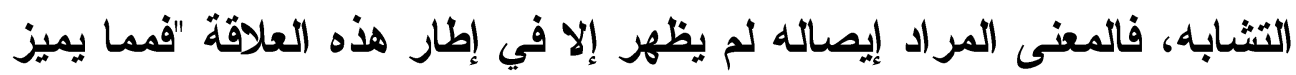

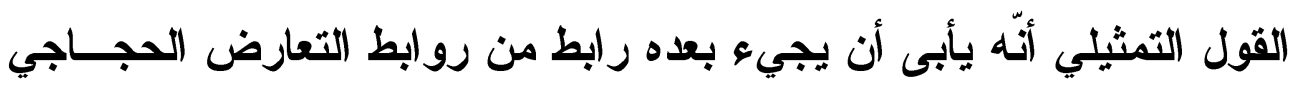

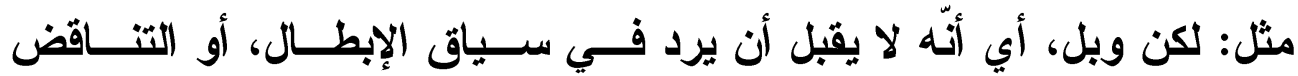

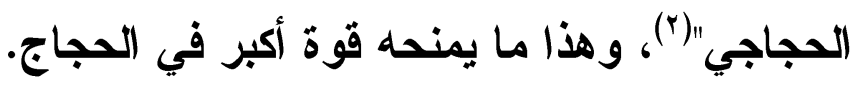

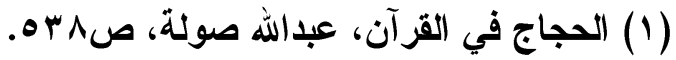

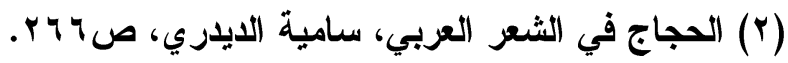


وقد وظف المتكلم الصورة في قوله: "أخذ القــوس باريهــا" لخدمــة مقصده الأي يرمي إليه، حيث أقام تثابهاً لحالة الخلافة مع القائم بها بحال

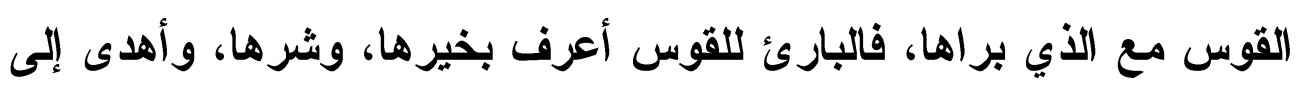
توتيرها، فكذلك الكائن على الأوصاف المعتبرة في الإمامة و الجامع لها يكون

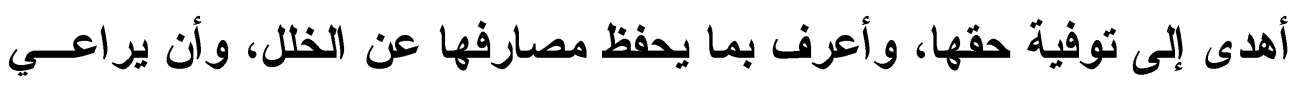

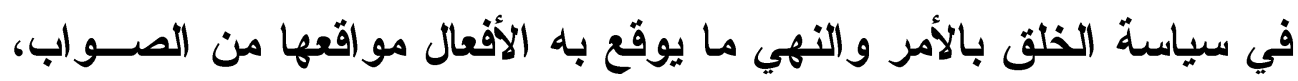

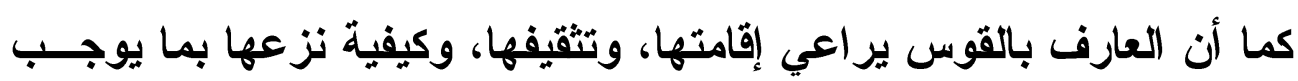
في سهامه أن تصيب الأغراض، وتقع في المقاتل (1).

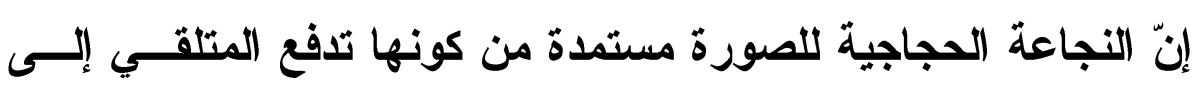

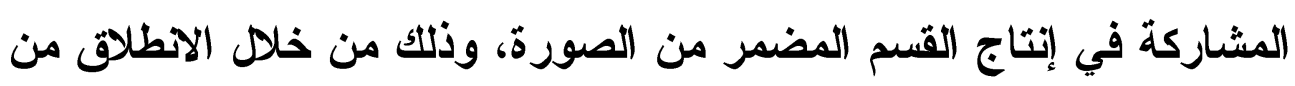
القسم الصريح.

ومن الأمثلة التي جاءت في سياق التمثيل قصة "عبد الملك بن مروان"

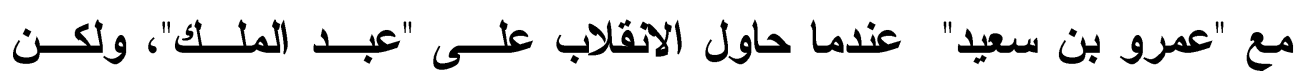

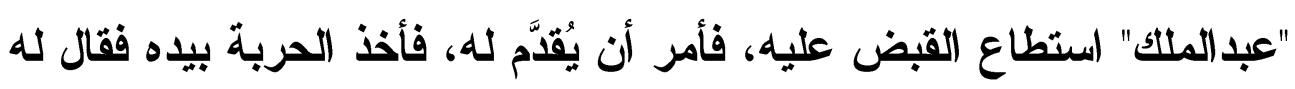

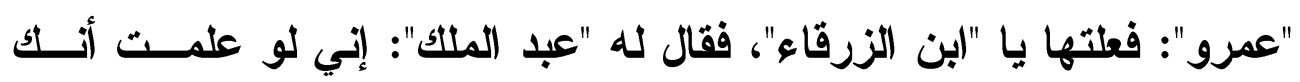

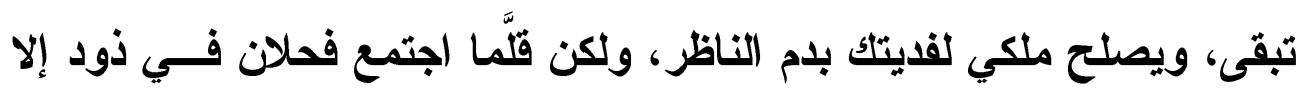
عدا أحدهما على الآخر، فرفع الحربة إليه فقتيله(؟).

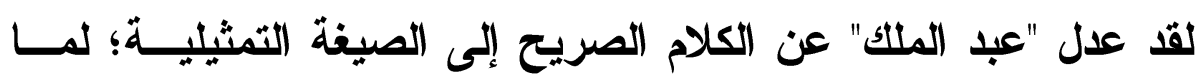

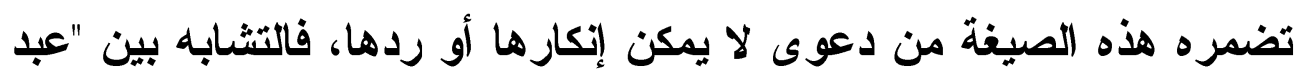

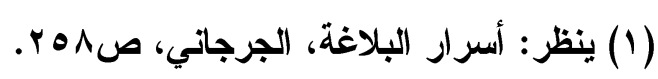

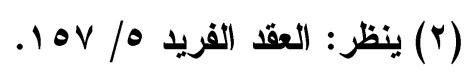


الملك بن مروان" و "عمرو بن سعيد" في سعيهم جميعاً للإمساك بزمام الحكم، ووجود أكثر من فحل في المجموعة من الإبل هو تثنابه في العلاقة، بمعنـى أن العنصر (أ) يمثل إلى العنصر (ب) ما يمثله العنصر (ج) بالنسبة للعنصـر (د) كما في هذا الثكل:

$$
\text { أ- عبد الملك }
$$

$$
\text { ب- عمرو بن سعيد }
$$

ج- الفحل الأول من الإبل د- الفحل الثاني من الإبل

وتكمن حجاجية التمثيل هنا بما ينطوي عليه من موضع يشكل فكرة أو رأياً هو إجماع محل المخاطبين، وهذا الموضع يكون بمثابــة مـــا يسـميه "تولمين" بقانون العبور من المعطى إلى نتيجة (') فالمعطى يتمثل في كونهـ لا يجتمع فحلان في ذود، فـ"عمرو" و"عبد الملك" كالفحلين يسعى أحــــهـا للسيطرة على الآخر، والتتيجة المتوخاة من هذا التمثيل لابـــــــن إقصــاء أحدها للآخر، حتى تتم له السيطرة والغلبة. لقد أدث الصورة التمثيلية دورًا رئيسًا في تكثيف الخطاب الحجاجي، وإبراز المعلومة التي يريـــ المرسـلـ إيصالها للمتلقي، والإقتاع بها، وهي أنّ الملك لا يمكن أن يثبــت ويسـتقر لأكثر من شخص.

ومن الصور التي تجاوز تأثيرها المتع الشكلية إلـى إنــارة انفعـالات المتلقي، ودفعه لاتخاذ سلوك، أو موقف محدد، قصة "سليمان بن عبد الملك" 
مع أضيافه من الأعراب حيث "حضر أعرابي سفرة "سليمان بن عبـــالملك"،

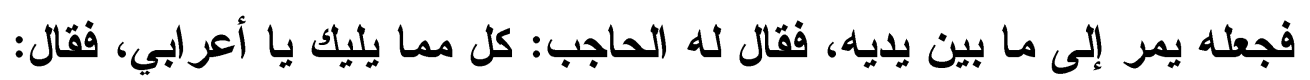

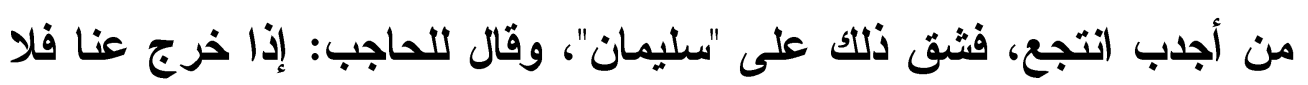

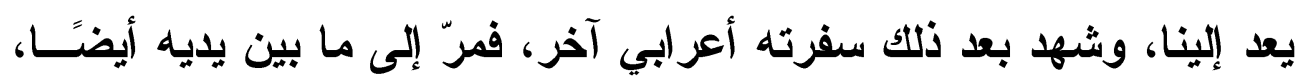

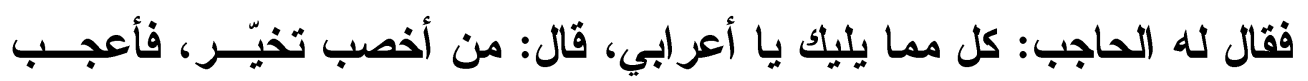

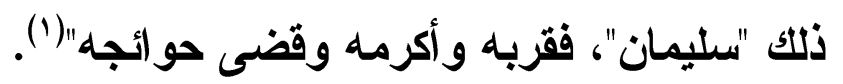
لقد اسنطاعت الصورة أن تكثف جـانبي الموضــوع الــــي انطــوى عليهما، وهما: الجانب السلبي وهو ما يسمى بالتقبيح، والجانسب الإيجـابي

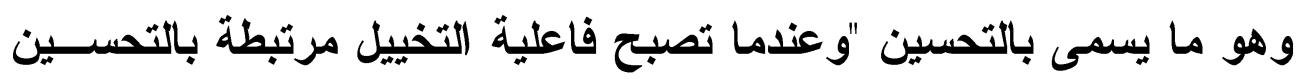

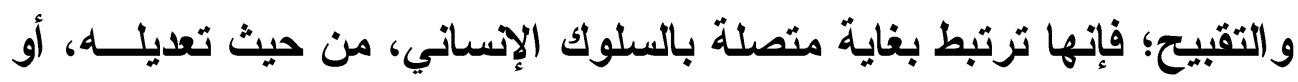

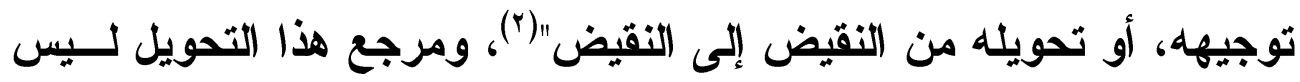

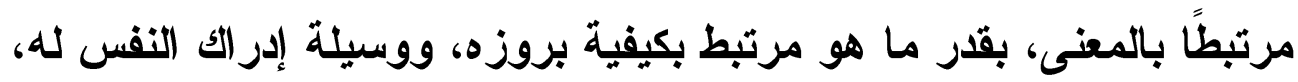

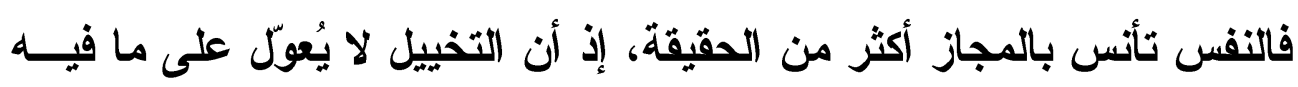

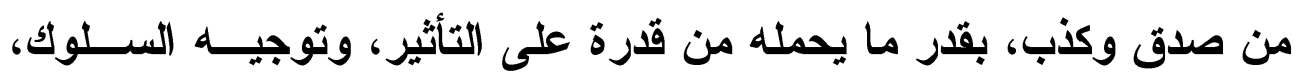

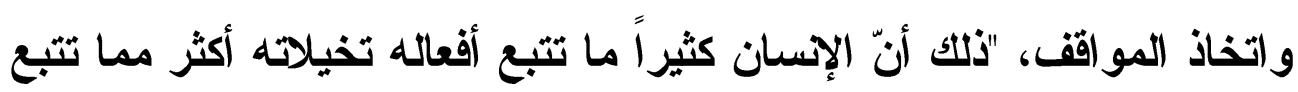

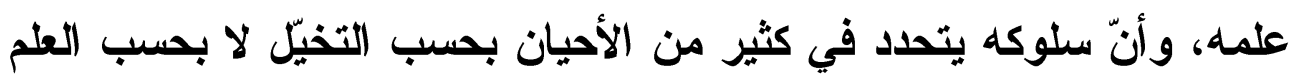

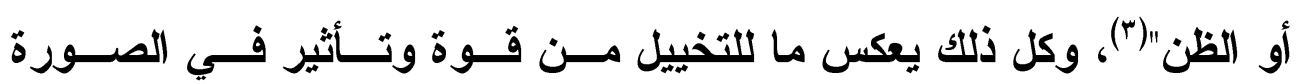

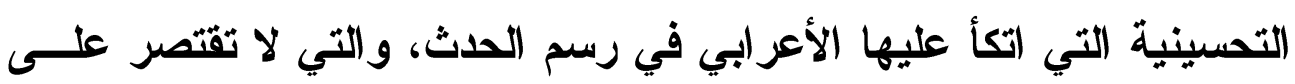

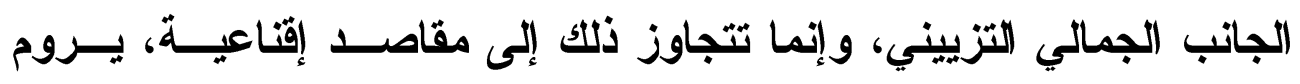

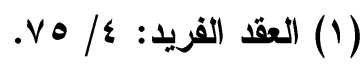

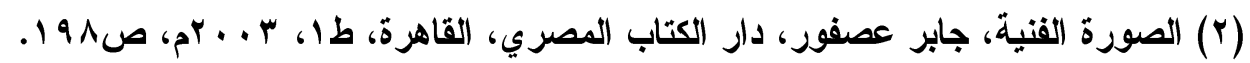

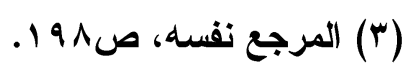




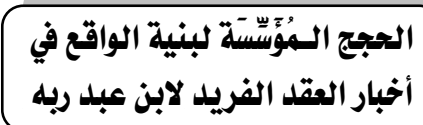

का 1 \& 1 ?

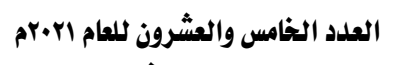

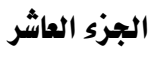

المتحدث فيها التأثير في المخاطب؛ من خلا إيصال المعنى في قالب قثــيب يحمل وجهة نظره، وكما أثثارت هذه الصورة اهتمام المتلقـي، واســتجلبت انتباهه، فإنّ الصورة السلبية التي رسمها الأول قد أثارت اشمئز ازه.

إنّ التخييل عملية موجهة تهدف إلى إثارة المتلقي، إثــارة مقصــودة

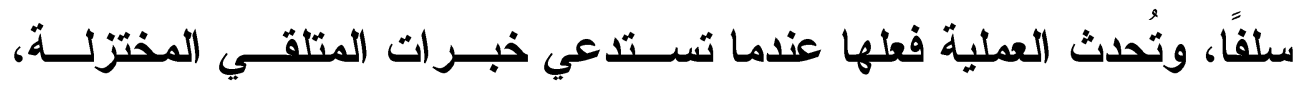
والمتجانسة مع الصور المخيّةة، فيتم الربط على مســتوى اللاوعـي مــن

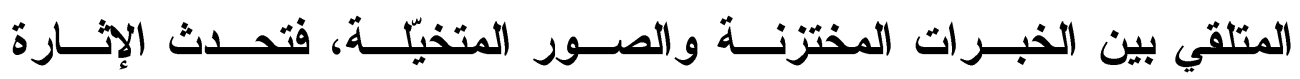

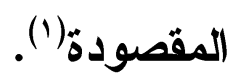

ولالكك يقول "حازم القرطاجني": "لما كانت النقوس قـ جُبلت على التنبه لأحاء المحاكاة والاتذاذ بها ... اثثتد ولوع النفس بالتخييل، حتى إنها ربما تركت التصديق للتخييل، فأطاعت تخيليها وأضاعت تصديقها"(؟)، لقد قامـــ الصورة التخيلية في هذا الخبر على سند منطقي، وذلك بغية توجيه الكلام، وتوجيه المتلقي إلى نتيجة ينبغي أن تقع، وقا استمدت هذه الصورة طاقتها الحجاجية من مادة واقعية، ومشاهدة متصلة بالبيئة، وهي الخصب فمشاهدة الخصب من أعلق المشاهد بذاكرة العربي، ومن أثثدها تأثير افي الوجيــــان،

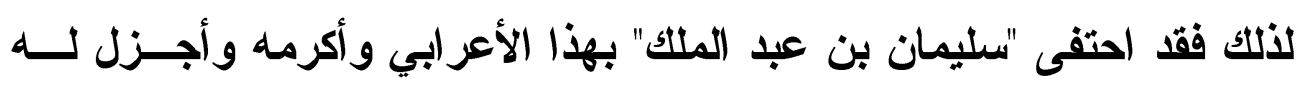
(العطاءو. (1) (1)

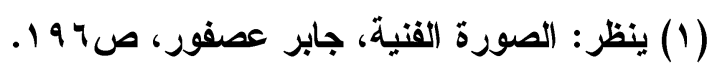

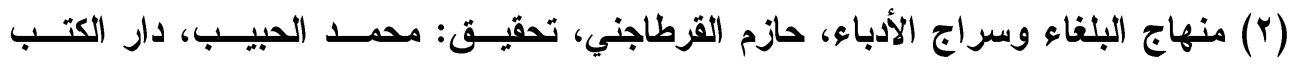

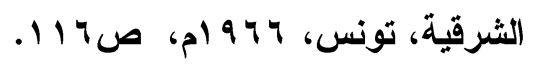

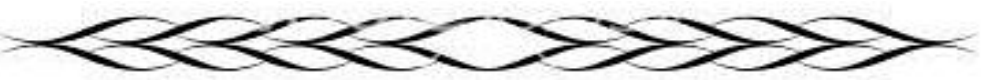


ومن الأمثلة التي اعتمدت على الكناية قصة "يزيد بن الوليد" لما بلغــه

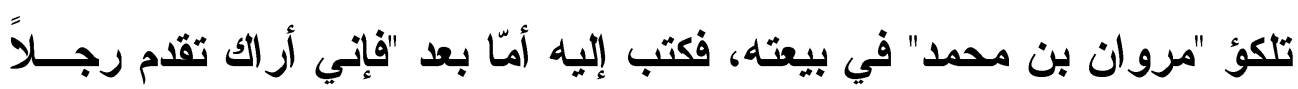

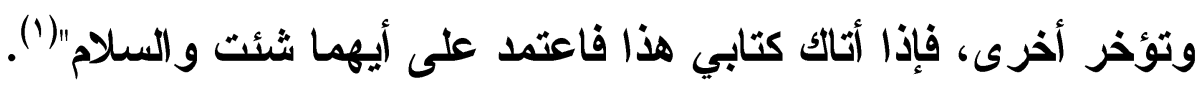
لقد كنّى "يزيد بن الوليد" عن حيرة "مروان بن محمــد" وتــردده فــي

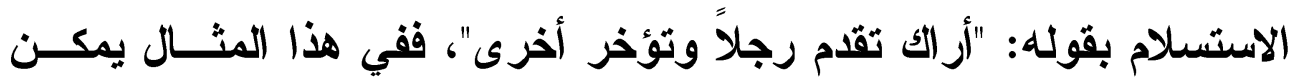

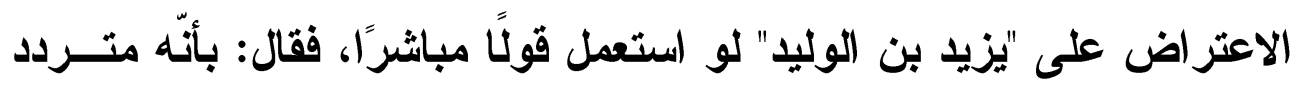

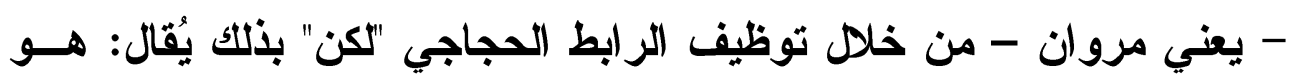

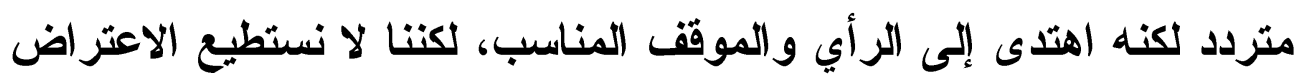

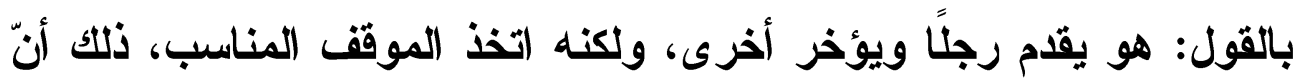

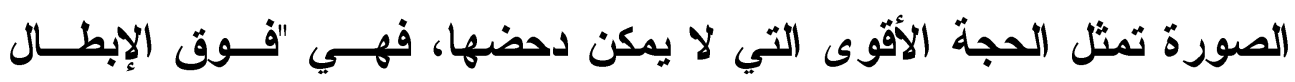

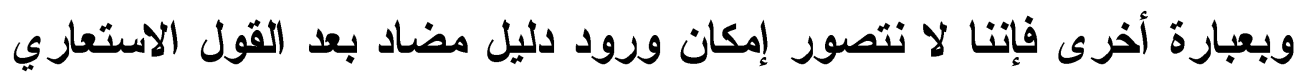

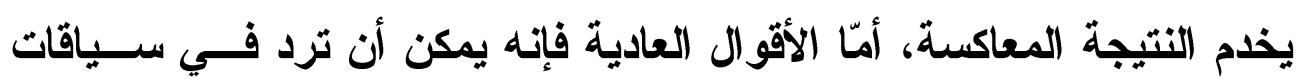

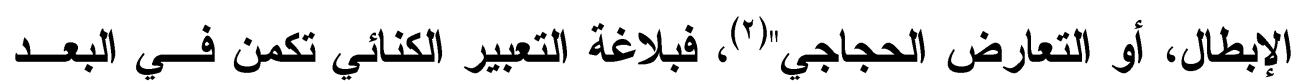

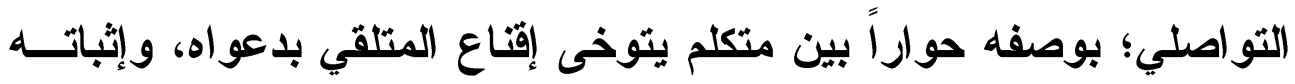

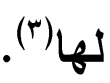

إنّ المتكلم لا يروم إخبار المتلقي بحيرته وتردده، ولكنه يروم إقناعـهـ

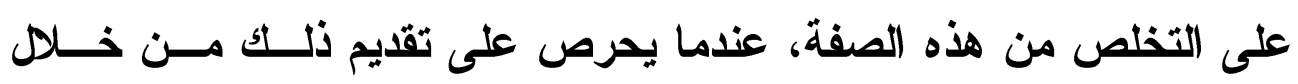

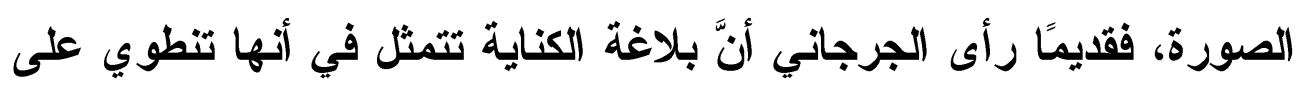

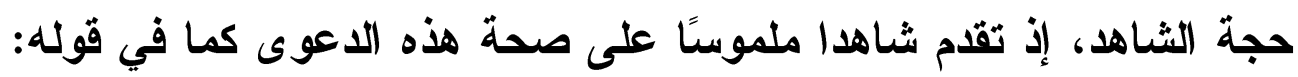

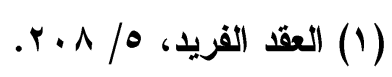

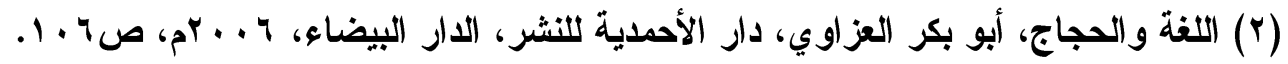

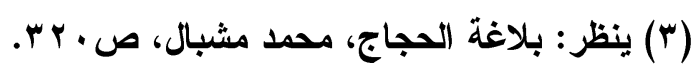




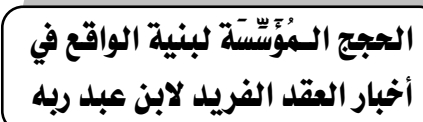

(1. 1 $1 \leqslant 0$

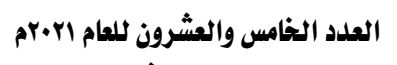

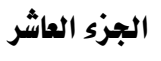

"أمّا الكناية فإن السبب في أن كان للإثبات بها مزية لا تكون للتصــريح ... أن إثبات الصفة بإثبات دليلها آكد، وأبلغ في الدعوة من أن تجـيء إليهــا فتثبتها هكذا ساذجاً غقلاً "(1).

وحديثاً أثشار الطر ابلسي إلى ذلك حين رأى أنّ الكناية "تعطينا الحقيقة مصحوبة بدليلها"(r)، وقد اقتضت جملة "يزيد بن الوليد" المتممسـة للصــورة "قاعتمد على أيهما شئت" حمل المتلقي على الاقتناع بدعوته، حيـث جعـل المتلقي يتولى هو نفسه الكثف عن مضمر هذا القول، والاتثقال من لازمسـه إلى ملزومه،، أو من الالالة الوضعية إلى الدالاة المستنبطة، والتي من شأنها أن تفتح تأويلات متعددة للمرسل إليه، حيث يضمر كلام المرسل أكثــر مــن معنى، فهو يدل على شجاعته وتصميمه في إنفاذ ما يريد، وكذلك يدل علـى عدم اكتراثه بالخصم، وتحمل تهايد له كذلك، وكل هذه المعاني والتــــئلات التي تحملها الصورة في طياتها تدفع المرسل إليه إلى التسليم، والرضــوخ للمرسل، وهذا ما وقع فعلاً. وفي موضع مختلف نقر أ استخدامًا آخر للحجاج القائم علــى الكنايـــة، وذلاك أن المتكلم قد يلجأ إليها لتحسين الأثياء أو تقبيحها، فقد يبالغ المتكلم في استحسان فكرة أو شخصية فيدفع المتلقي إلى استحسان ذلك، وبالعكس عندما يستقبح المتكلم الشخص أو الفكرة فإنه يدفع بالمتلقي إلـى اســتقباح ذللك، فالتحسين والتقبيح يمثلان وسيلتان حجاجيتان، تهدفان إلى توجيه ذهن المتلقي، أو التأثثير فيه، ومن الثواهد على ذلك قصـــة "ابــن الأهـــتم" مـــع

(1) دلاثل الإعجاز، عبد القاهر الجرجاني، قرأه وعلق عليه: محمود شاكر، دار المدني بجــة،

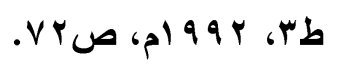

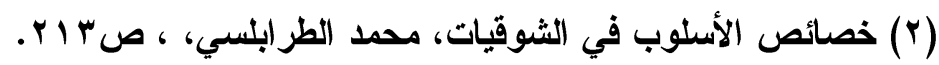


الرسول -صلى الله عليه وسلم- حيث سأل "(بن الأهتم" عـن "الزيرقــان"،

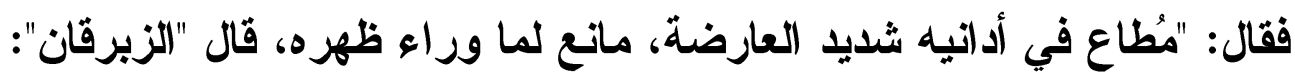

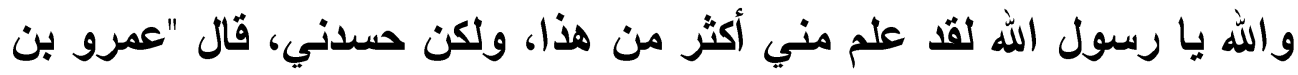

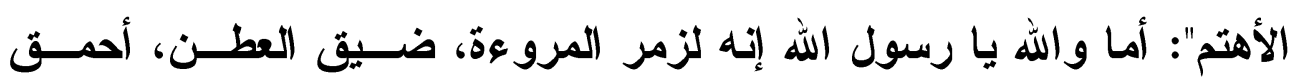

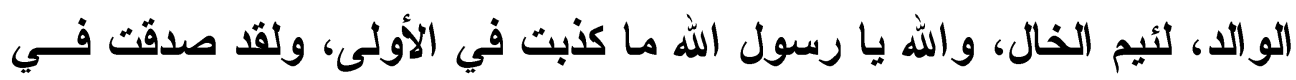
الأخرى، رضيث عن ابن عمي فقلت أحسن ما فيه ولم أكذب، وسخطت عليه

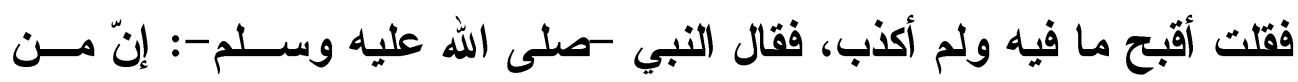

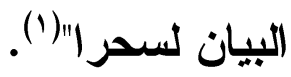

لقد اعتمد "ابن الأهتم" في مدحه "للزبرقان" على إبراز بعض ما لايـــه

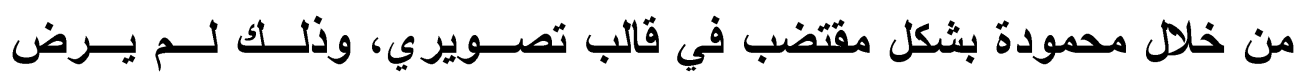
"الزبرقان" حيث رأى في هذا التصوير غضيًا من مكانته، فالأي لا يعدو أمره

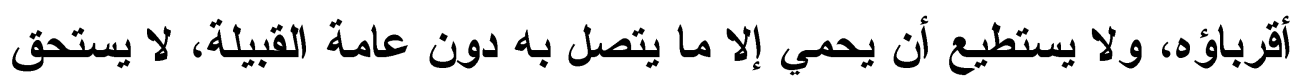

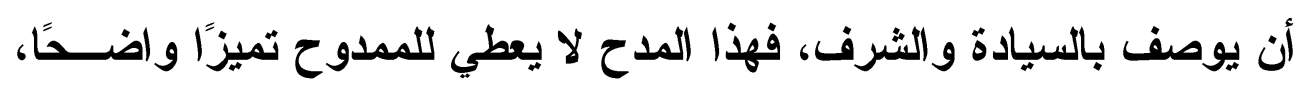

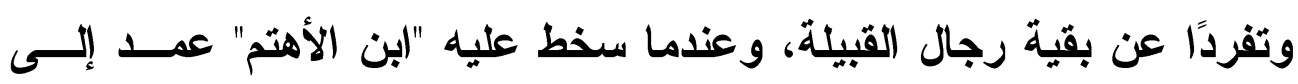

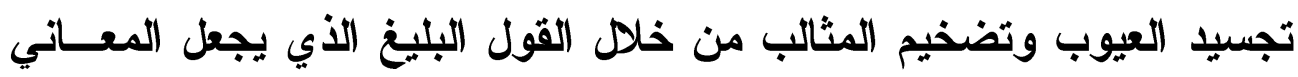

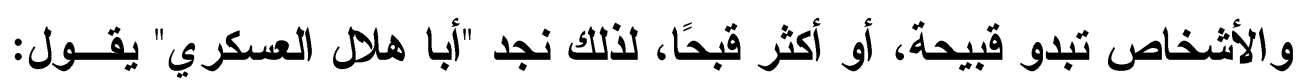

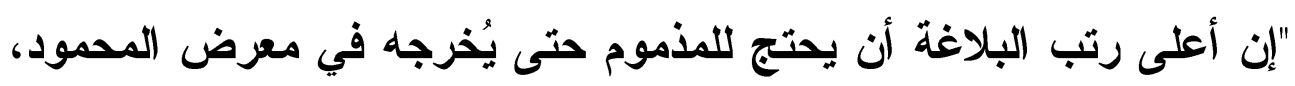

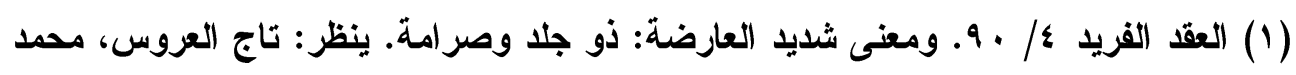

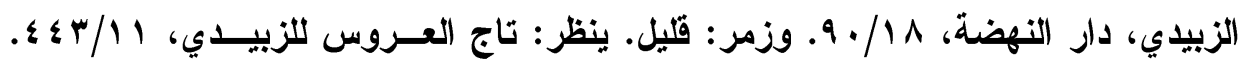

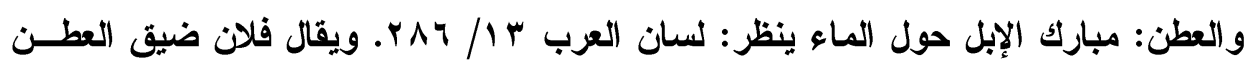

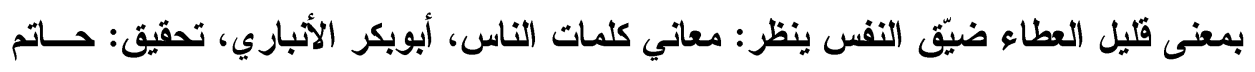

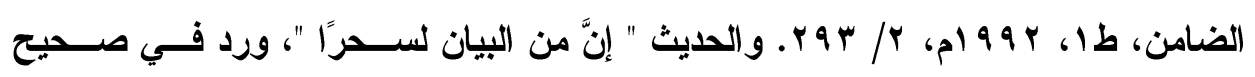

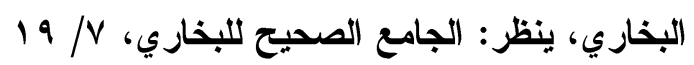




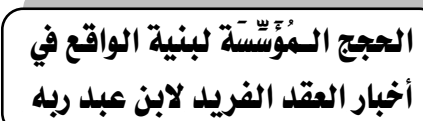

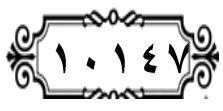

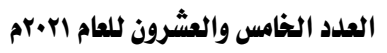

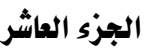

وللمحود حتى يصيره في صورة المذموم"(1)، ولن يتحقق ذلك إلا بالأساليب البياتية التي تجعل الجميل أكثر جمالًا والقبيح أكثر قبحًا(†).

لقد سعى "(بن الأهتم" إلى الغض من مكانة خصمه، من خلال تجريـــه من معاني السيادة والشرف، وقا اكتسب هذا المعنى قوته من خلال الكنايات التي أوردها، فهو ضيّق العطن، كناية عن قلة الصبر والبخل، زمر المروءة

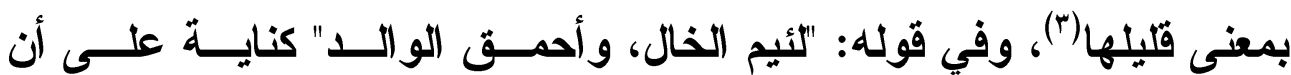
المخاطب غير معرق في الثرف والسيادة.

لقد اكتسبث الصورة البياتية قوتها وفعاليتها التأثيرية من خلال صدقها ومطابقتها للواقع، فقد جعل "حازم القرطاجني" للمعــاني الصـــادقة المرتبــة

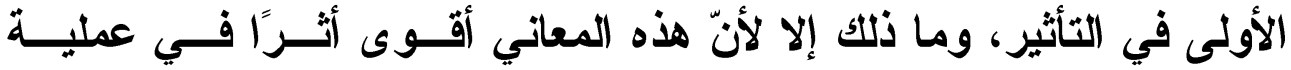

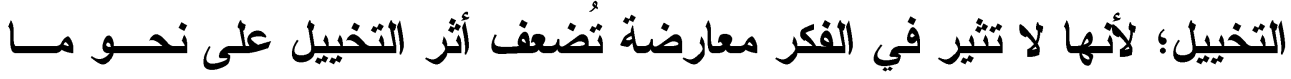
تفعله المعاني الكاذبة، أو الأقاويل ظاهرة البطلان (ء). إنّ براعة الإقتاع ترتبط بقدرة البليغ على تغيير وقع المعاني على نفس المخاطب؛ فبذلك "تصبح الصورة القنية وسيلة للتحسين، والتقبيح، وتـؤدي إلى ترغيب المتلقي في أمر من الأمور، أو تنفيزه منه"(ه). (1) الصناعتين، أبو هلال العسكري، تحقيق: علي البجــاوي، المكتبـة العصــرية، بيـروت، 999 ام، صro 99.

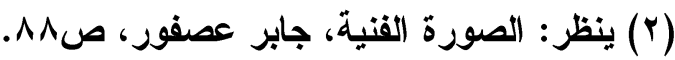

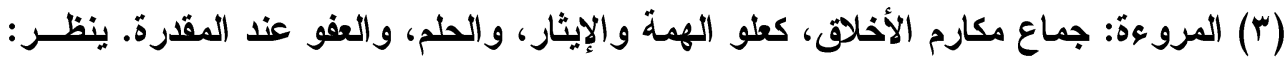

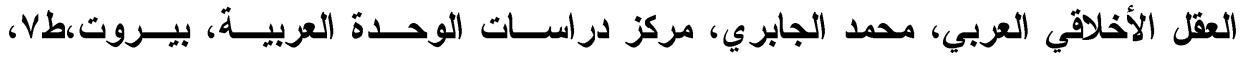

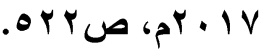

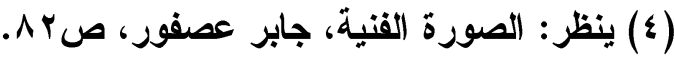

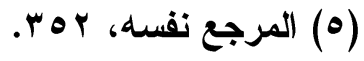


وتتحقق هذه الغاية عندما يربط البليغ المعاني الأصيلة التي يعالجهـا

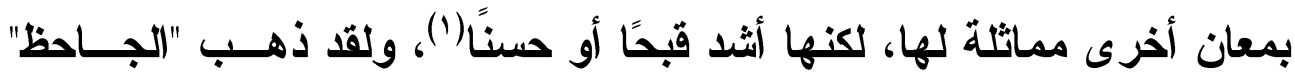

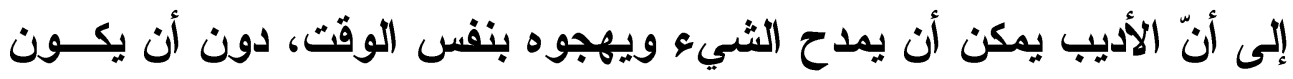

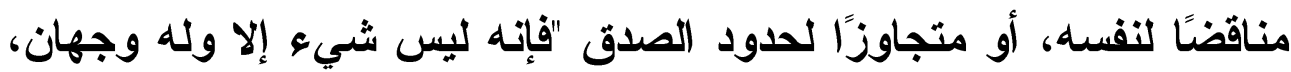

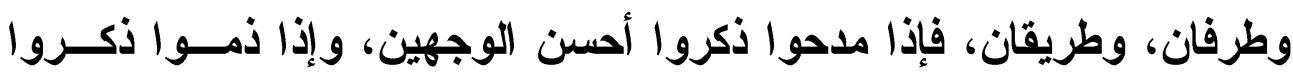

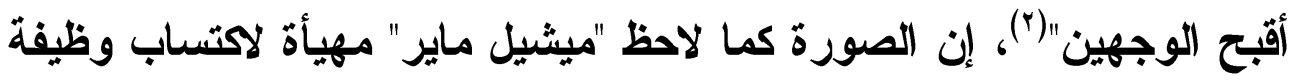

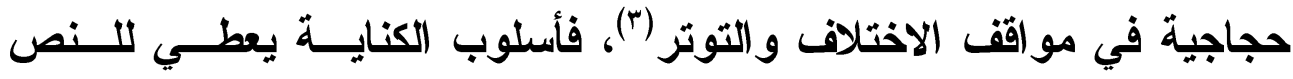

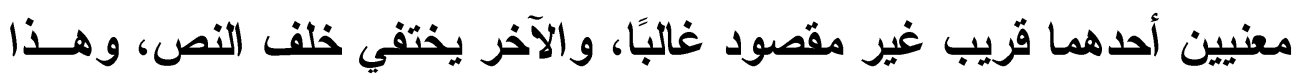

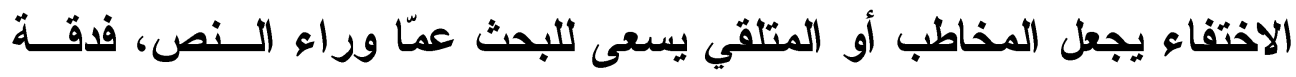

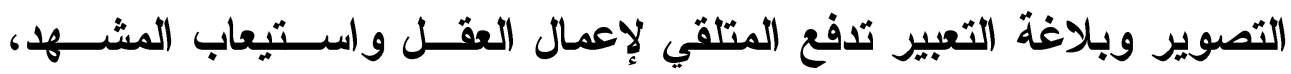

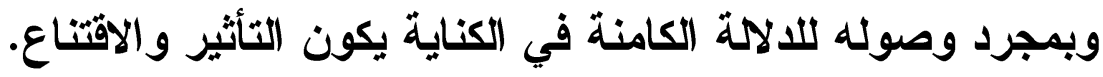
وفي مقابل الأمثلة السابقة نجد ضرباً من الأمثثة اعتمد في بنائها على

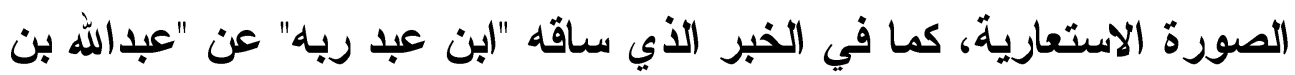

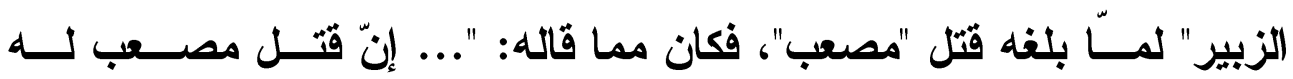

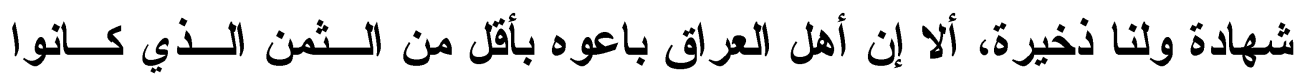

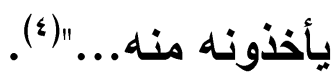

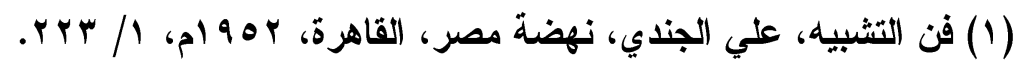

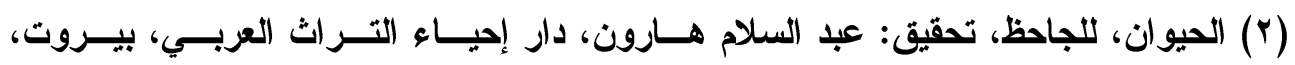

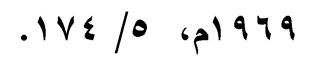

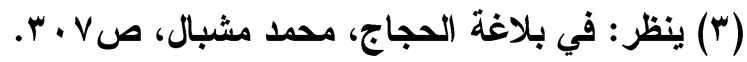

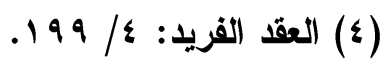




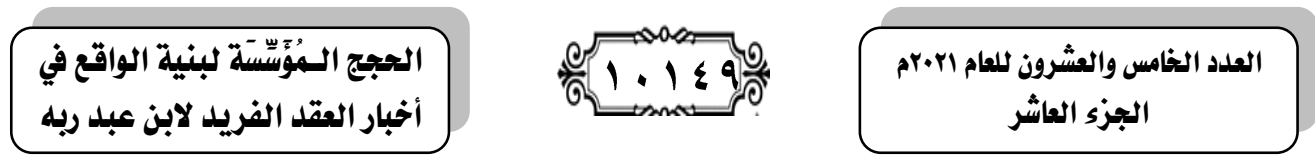

لقد خاطب "(بن الزبير" أهل مكة من خــلال ألفــاظ البيــع والثــراء، و استلاهم هذه الصورة من مستودع حجاجي مشـــرك، فــالقوم مشــهورون

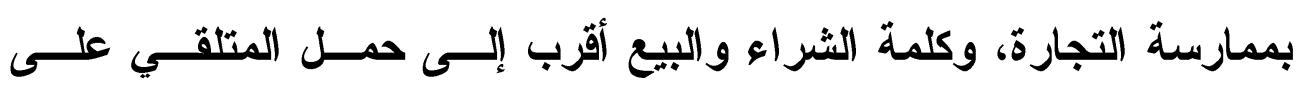
الاقتتاع، لارتباطهما بالواقع المعيش، ولقد عدّ "الجرجاني" الاســتعارة مـن دعائم الحجاج المهمة، وهو ما أثبار إليه بقوله: "أمّا الاستعارة فإن ســبيلها سبيل الكلام المحذوف في أنك إذا رجعت إلى أصله وجدت قائله، وهو يثبـــ أمرًا عقليًا صحيحًا، ويدعي دعوى لها شبح في العقل"(')، فالاستعارة بمثنابة البينة تجاه قضية ما، ولا سبيل للعقل أن يردها كحجة، لقد أراد "ابن الزبير" من خلال هذه الاستعارة تهجين وتقبيح فعل أهل العراق مع أخيه "مصــعبه"، و إقناع المتلقي على أنّ الخيانة طبع متأصل في نفوس أهل العراق، ومتمكن من قلوبهم، فهم لا يقيمون ولاعهم لقادتهم على بعد ديني وأخلاقي، بل على

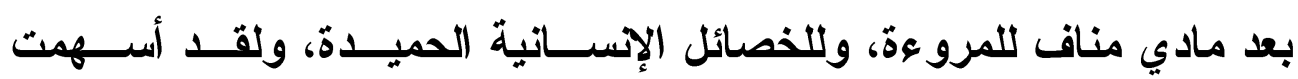
الاستعارة في تقريب هذا المعنى، وتثبيته في ذهن السامع. ومن الشواهد على الاستعارة ما ورد على لسان "قطري بن الفجـاءة" عندما حذر أصحابه من الركون إلى الانيا "فإني أحذركم الانيا فإنهـــا حلــوة خضرة حُفت بالشهوات، وغُرت بالآمال، غدارة، ضرارة، حائلة، زائلة"(؟). لقد شبه المتكلم الانيا وسرعة انقضائها بمنظر الربيع الجميل، ووجـهـ الثبه سرعة انقضاء هذا المنظر المبهج الجميل، فكان لانتقاء لفظة الخضرة للصورة الاستعارية دور فعال في صناعة الحجـــاج، فهـي مــن المخـزون الحجاجي المشترك المستمد من البيئة المشاهدة، فالخضرة من أجمـل مـــا

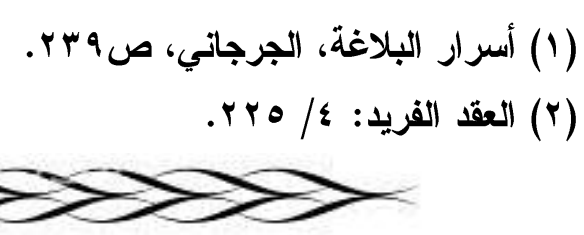


يروق لابن الصحراء، ويغريه، حيث إنها تزرع البهجة في القلوب، وتبـرز

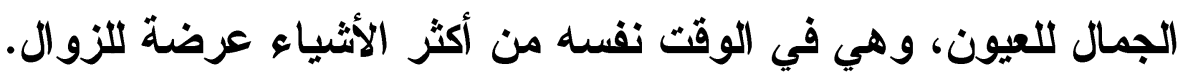

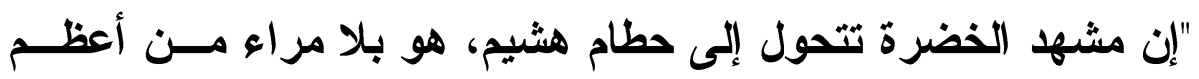

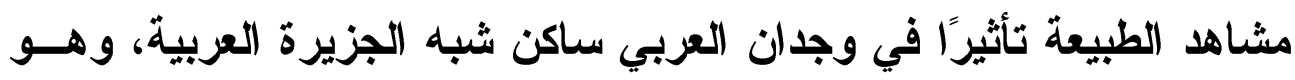

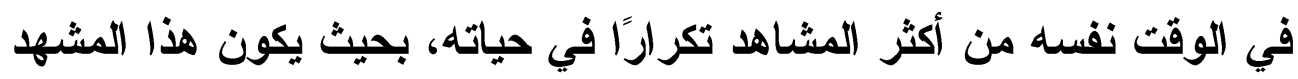

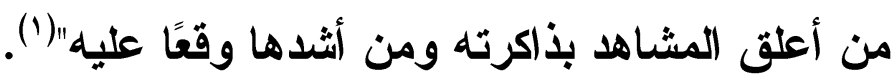

لقد قامت هذه الصورة على الدعوة للجهاد، والتحذير من الركون إلـى

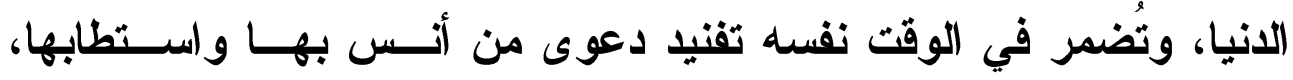

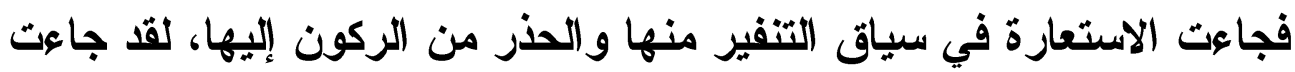

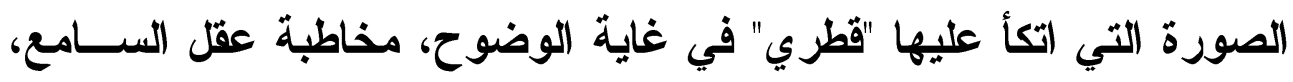

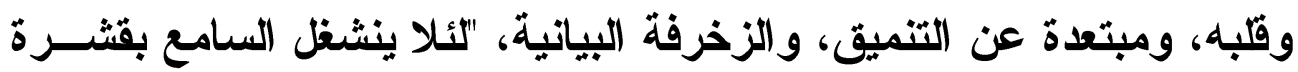
التراكيب المنمقة، والزخرف الباطن، ويذهل عن لب التعليم والقوت المغذي

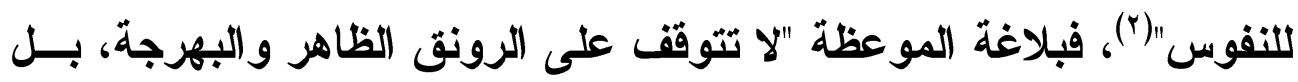

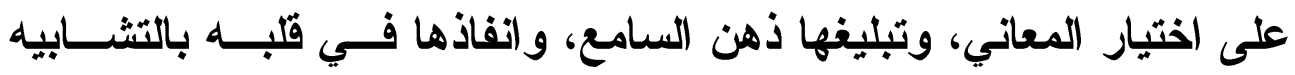

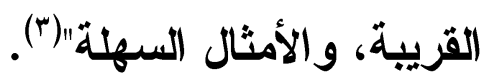

ومن شواهد الاستعارة ما أورده "ابن عبد ربــه" عــن "عبــالله بـن

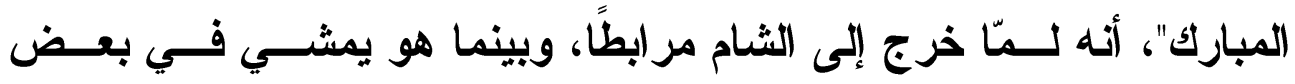

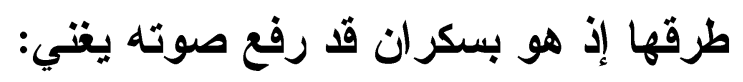

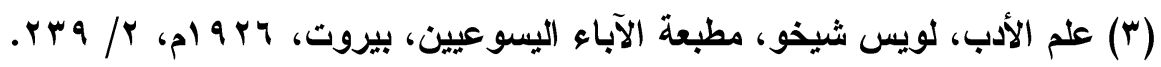


أخبار العقد الهُوَستِّة لبنية الواقع فيل لابن عبد ربله

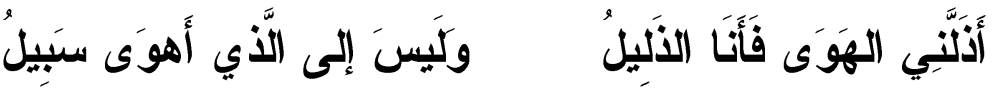

فأخرج ورقة من كمه وكتب البيت، فقال له أصحابه: أنكتب بيت شعر

سمعته من سكران؟! قال: أما سمعتم رب جوهرة في مزبلة (1)

لقد عدل "ابن المبارك" عن المعنى الحقيقي الحرفــي إلـــ الاســتعارة

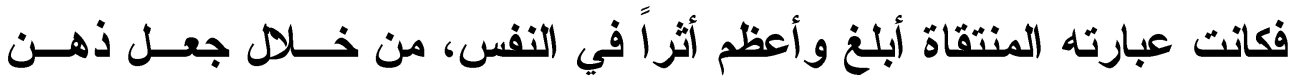
المتلقي يتجول في الخيال؛ بحثًا عن المعنى المقصود، حتى إذا أدركه تمكـن فئن في نفسه، واستقر في ذهنه، فالدرة لا يمكن أن تفقد قيمتها فئسي أي مكـــان تحل فيه، وكذلك الكلام الجميل لا يفقد رونقه، وبهاءه، مهما تفاوتت مكانــة

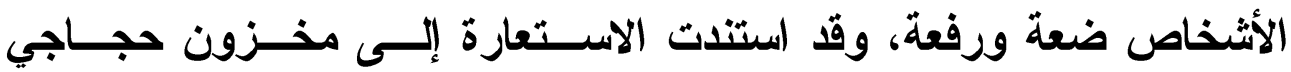

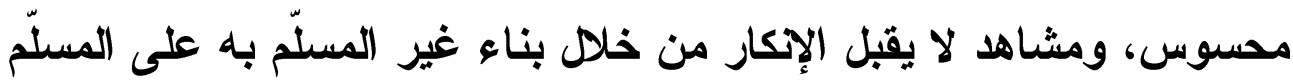

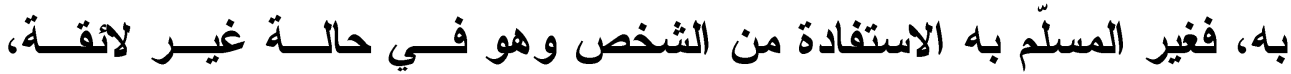

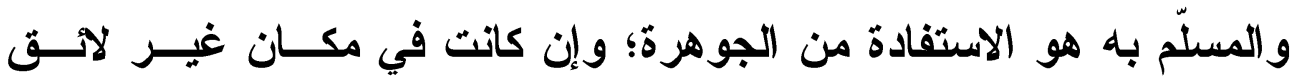
"فالاستعارة المصية تتضمن ما لا تتضمنه الحقيقة من زيادة وفائدة"(†). ومن شواهد الصورة التي وردت في سياق حجاجي ما نجده في خبـر

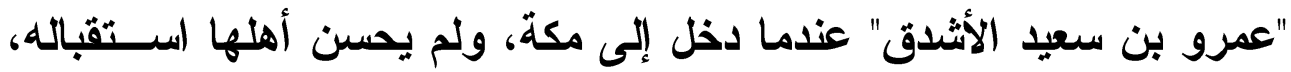

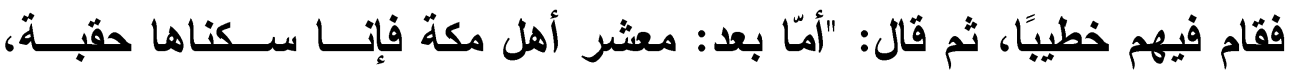

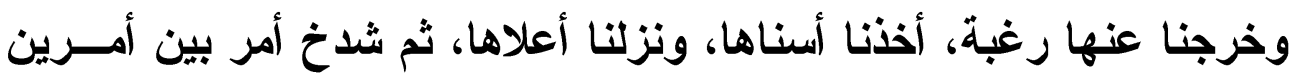

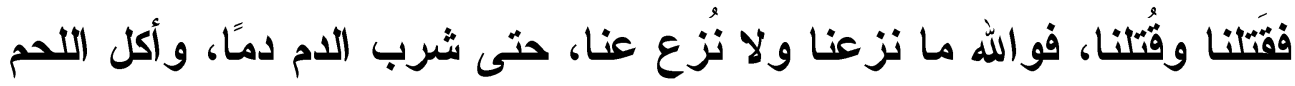

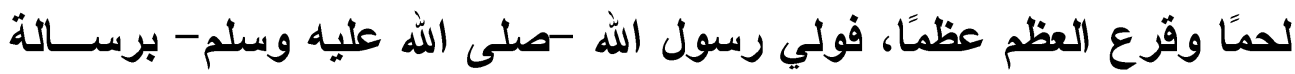

(1) - 1) ينظر: العقد الفريد 10/V.

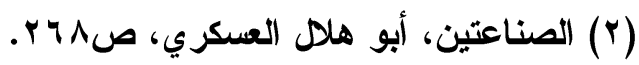

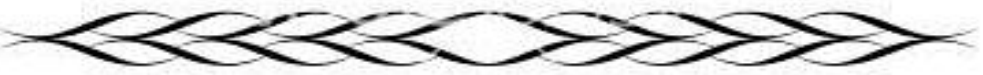




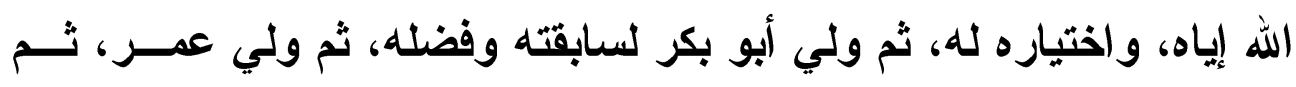

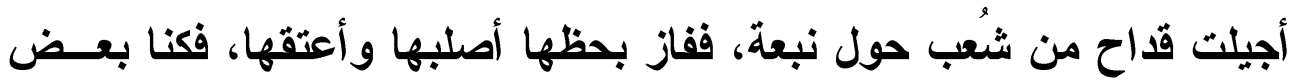

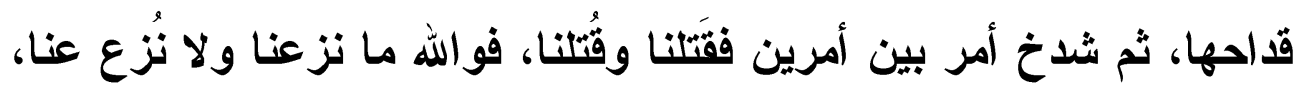
حتى شرب الدم دمًا وأكل اللحم لحمًا وقرع العظم عظمًا، وعاد الحرام حلآًا، وأُسكت كل ذي حس عن ضرب مهند" (1").

لقد حاول "عمرو" أن يعيد قراعة الأحداث التي وقعت بعد مقتل عمـر

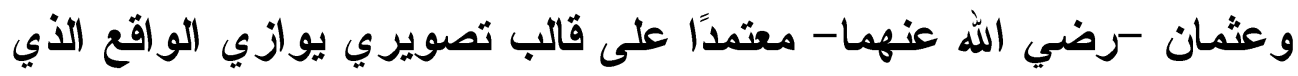

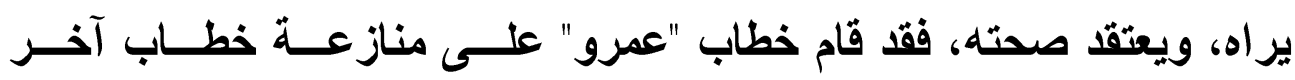

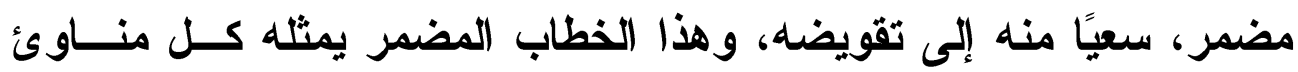

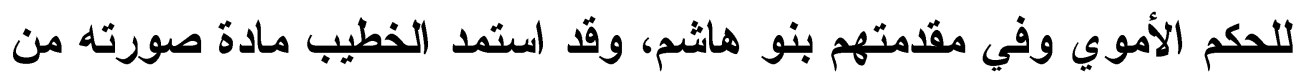

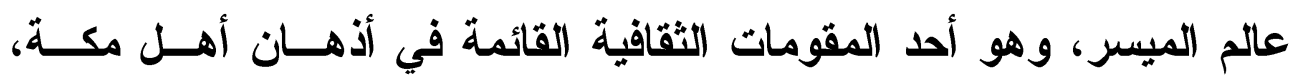
و المنسربة في عمق تفكيرهم، ومن شأن هذه المقومات الثقافية المتجذرة في

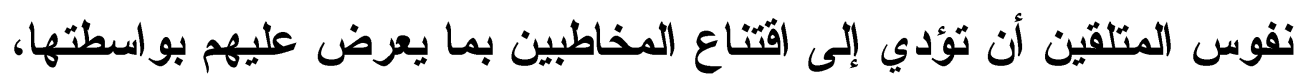

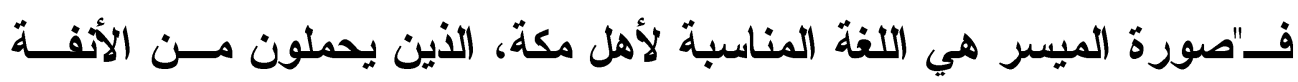
و الكبرياء ما جطهم يتقاعسون عن استقبال الوالي، ويهونون أمره، ويهمنا

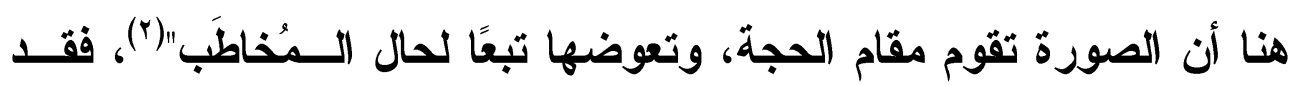
اتخذ الخطيب من الكنايات والاستعار ات إطارًا يجسد من خلاله عالم الميسـر

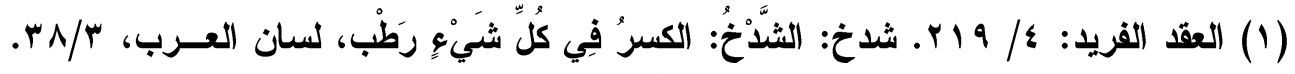

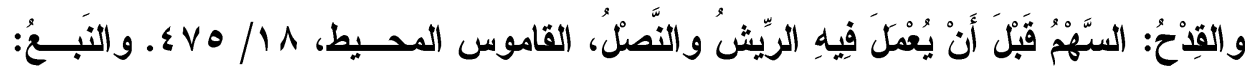

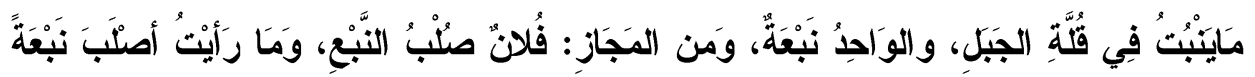

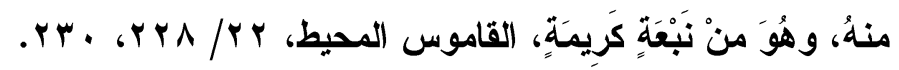

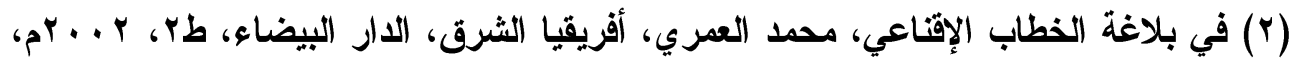


الموازي لعالم الخلافة، فكلا العالمين يطمحان إلى الغلبة والســيطرة علــى الآخر، ولا ينال الغلبة إلا من كان لايه حظ من قوة وصبر وذكاء؛ لذا فقــــ جاعت الكنايات والاستعار ات لتوجيه دلامة الكلام وجهة حجاجية مخصوصة، فقي قوله: "قفاز بحظها أصلبها وأعتقها" كناية عن عثمان رضي الله عنــهـ وهو من بني أمية، وجاعت الاستعارة مكررة أكثر من مرة "حتى شرب الام دمًا و اللحم لحمًا وفرع العظم عظما" لتحرك في المتلقي الاحساس بعظمة بني أمية، وأحقيتهم بالملك والخلافة، ومن ثم الاقتناع بحكمهم والتسليم لهم. فالاستعارة هنا لا ترتبط بالوظيفة الإخبارية بقدر مـــا تــرتبط باتخــاذ موقف معين، فبذلك تتجاوز نقل محتوى القول إلى حمل المتلقي على التسليم بموقف الخطيب، "وبهذا الفهم لا تصبح الصورة شيئًا ثانويًا يمكن الاستغناء عنه، وإنما تصبح وسيلة حتمية لإدراك نوع متميز من حقائق تعجز اللغــة العادية عن إدر اكه، أو توصيله|'(1). ومن الصورة الاستعارية التي جاعت حاملة في طياتها قدرًا كبيرًا مسن التأثير والإقناع، ما جاء في قصة أحد الثعراء الأين دخلوا على "يحيى يـن

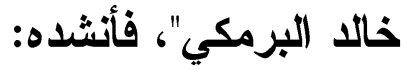

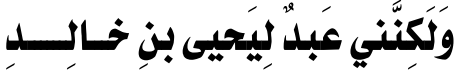

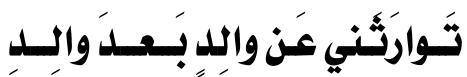

سَأَلَتُ النَلَدى هَلَ أَنْتَ حُر فَقتال : لا

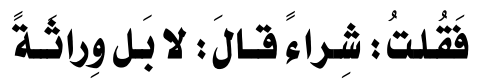

فأمر له بعشرة آلاف(؟).

(1) ينظر: الصورة القنية، جابر عصفور، صזم r.

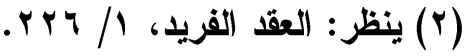


والثـاهد في هذه الأبيات قوله: "سألت النـــى" حيــث شــبة النـــى بالإنسان، ثم حذف المشبه وأثار إلية بثي من لوازمه.

إن المعنى الأي يرمي إليه الثـاعر هو تمكن هذا الكــرم مــن نفـس الممدوح، وور اثثه لله كابراً عن كابز، وهذا المعنى يصعب إيصاله لو اختــار الثـاعر الاستخدام الحرفي، ولقد شيّدت الاستعارة هنا واقعًا آخــر اســتـاع الشاعر من خلاله إثبات وجهة نظره، وإيصال ما يريده.

ومن الثواهد القائمة على الصورة الشعرية هـــا الخبــر وهــو "أنّ "المنصور" لـــا أر اد الخروج إلى الثام صعد المنبر، وقال:

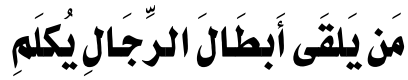

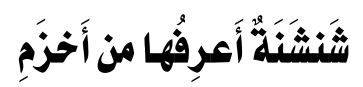
مهلًا مهيًا زوايا الإرجاف، وكهوف النفاق، عن الخوض فيما كفيـتم،

$$
\text { و التخطي إلى ما حُّرتم..."(1"). }
$$

لقد توخى الخطيب في استهلاله الاستحواذ على السامع، وإثارة خوفه؛ لارء إثارة الفتنة ومناوأة السلطان، من خلال إظهار ضعف خصمه، وهو ما يمثثله الثطر الأول من البيث، ويتمثل كذلك فـي قولـــه: "زوايــا الإرجــاف وكهوف النفاق" ومن خلا إبراز المنصور لنفسه بصورة البطل الذي لا يكاد يـزم، وهو ما يمثله الشطر الثاني من البيث. لقد أحسن "لمنصور" اختيار الشاهد الذي يخدم الغــرض الحجــاجي، ويثير وجدان المتلقي، وذلك بغية حمله على الإذعان والتسـليم، فــالتقريع يقوم على توجيه "التوبيخ والملامة لحمل المخاطب إلى إنجاز قصد عظيم"()، 
فهو بذلك يستثير السامع لحمله على إنجاز فعل ما، أو الكف عن فعل مــا، فالحجة ليست المعنى اللفظي نفسه، أي أنه شجاع؛ بل هو العنصــر الـــي يستحضره المتكلم للمحاجاة، ويجعله ماتثلا بـين أعـين المخــاطبين وفـي أذهانهم")، حتى تثرسخ الحجة من خلال الصورة التي يأتي فيها المعنى، أو ما سماه "عبد القاهر الجرجاني" بمعنى المعنى، "فعنى المعنى يــر ادف فـي هذا التحليل التداولي الحجة النموذجية، أو الاستدلال البلاغي"(؟). ومن الثواهد التي تجسدت في بناء شعري قصة "أبــي نُــوَس" مـــع مجموعة من الشعراء جمعه بهم مجلس، وأنشد كل واحد أجمل ما لايه من الشعر، فلما انتهوا إلى "أبي نواس" أنشد داليته المشهورة:

واشرَب عَلى الخمــر مــن

$$
\text { لا تَبَكِ هنداً ولا تَطرَبَ إلىى دَعدِ }
$$

حَمرَاء كالاورَدِ

$$
\text { حتى انتهى إلى قوله: }
$$

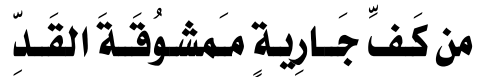

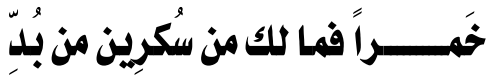

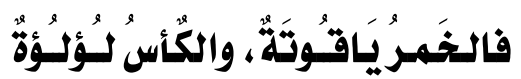

تُســـــقِيكَ منز يَدِهَا خَمَرَاً ومنَ فَهِهَا

فسلم له الجميع بتقدمه وريادته(").

لقد جاءت الوظيفة الجمالية التزيينية في البيتــين الأخيـرين تابعـة، وخادمة للوظيفة الأساس المتمثلة في الإقناع والتأثير، فصورة تثبيه ريــث الجارية بالخمر جاعت في سياق تحريك عواطف المتلقي من تزيين، وتعظيم،

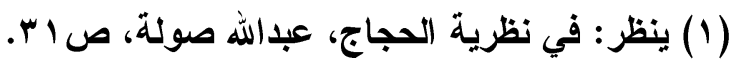

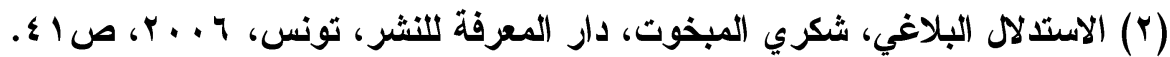

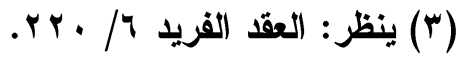




\section{الترقير الدولخ 2356-9050

وتحبيب، حيث نزع الثشاعر إلى تزيين الموضوع والاحتفاء به بنــاء علــى

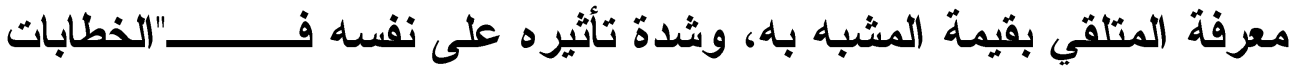

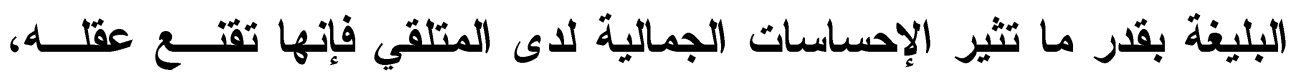

وتثير أهواءه، وتحمله على القيام بأفعال محددة"(1).

لقد طرحت هذه الصورة إجابة عن سؤال ضمني؛ عـن لـــذة الوصـل

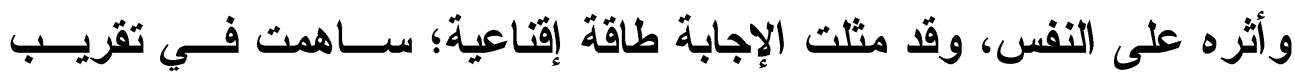

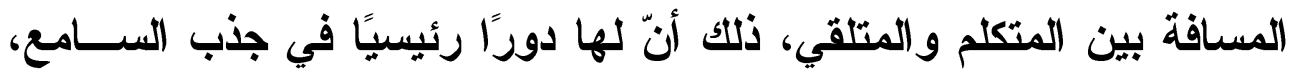

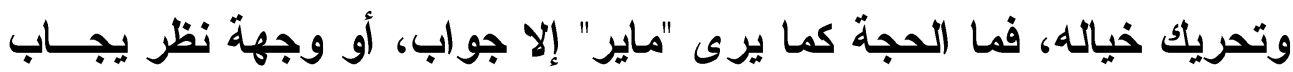

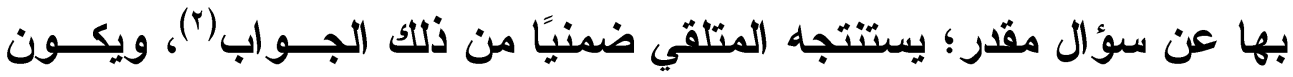
ذللك في ضوء المقام.

لقد أورد الثاعر الفعل "تسقي" مضافًا إلى كاف الخطاب؛ ليحمل بعـدًا

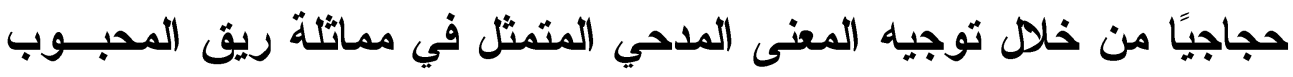

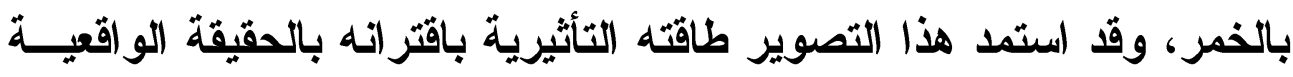

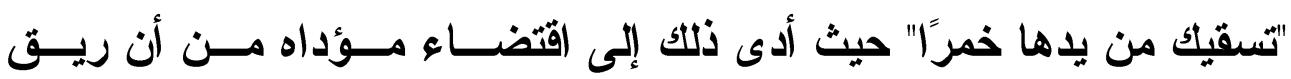

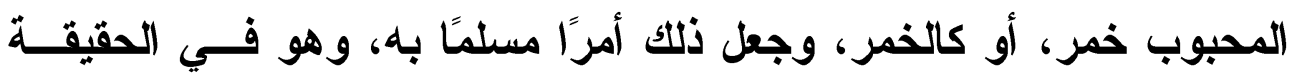

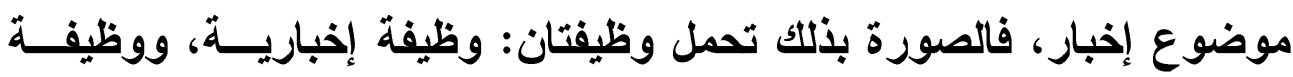

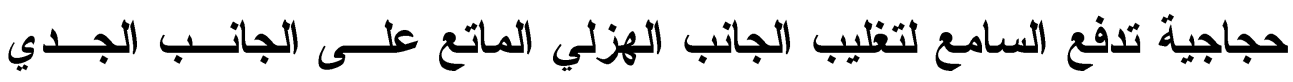

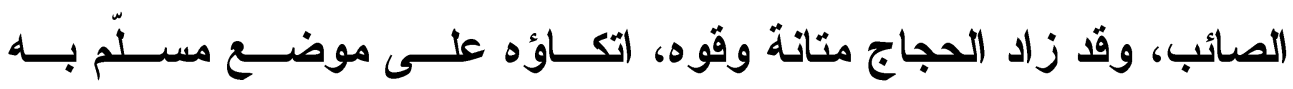

(1) عن بدايات الخطاب العربي الحديث نحو بلاغة موسوعية، محمد مشبال، كنوز المعرفـة،

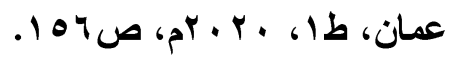

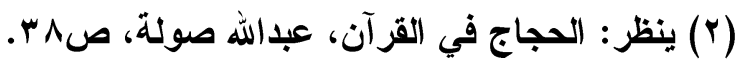




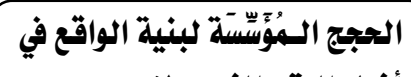
أخبار العقد الفريل لابن عبد ربله

اجتماعيًا؛ وهو اقتران الخمر باللأة سواء أكان ذلك على الصعيد الاعتقــادي والأهني، أم على الصعيد الواقعي.

وختاما، لقد تبين لنا من خلال الوقوف على حجاجية الصورة البلاغية ما ترمي إليه من إقناع للمتلقي، ومن ثم التغيير فــي سـلوكه، ويمكـن أن نرصد ما يتميز به الحجاج بالصور البلاغية عن الحجاج العادي بأمرين:

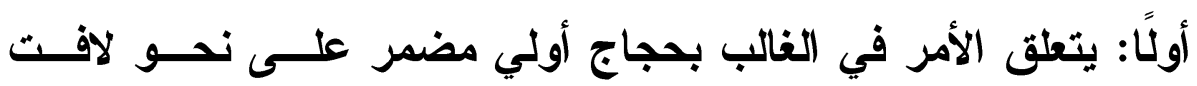
للنظر؛ حيث تؤول تأثير اته الإقناعية أساساً إلى الواقع المباشر للتمظهـر ات ات المجازية المحدثة.

ثانًا: إن الحجاج بالوجوه البلاغية يساهم على نحو واضح في الحجاج بالإغراء، وعلى إيراز الإضاءات الجذابة(1).

مقالتان في الحجاج، أبو بكر العزاوي، مارك بنوم، ترجمة: محمد البقالي، بحث منثــور 


\section{هصادر البحث وهراجعه}

أولا ـ المسادر :

العقد الفريد، ابن عبد ربه الألدلسي، تحقيق: مفيد قميحة، دار الكتـبـ

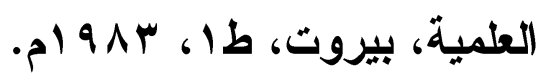

ثانيا ـ المراجع:

- أسرار البلاغة، عبد القاهر الجرجاني، قرأه وعلق عليه: محمود شــاكر،

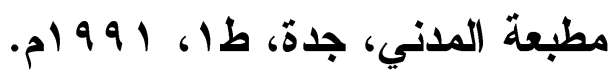

- الاستعارة والحجاج: ميشيل لوجيرن، تعريب: الطاهر وعزيز، ضمن مجلة

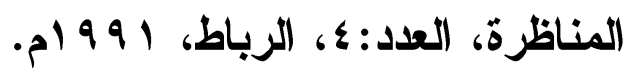

- الاستـلال البلاغي، شكري المبخــوت، دار المعرفــة للنشــر، تــونس، . . .

- بلاغة النادرة في الأدب العربي، سليمان الطالي، كنـــز المعرفــة، طا، .0 p. 10

- التمثيل في التراث النقدي والبلاغي حتى نهاية القرن الخامس الهجـري،

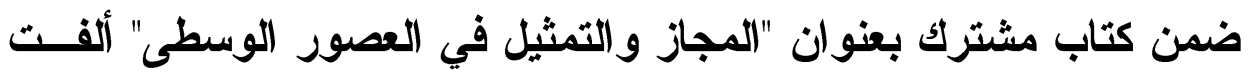

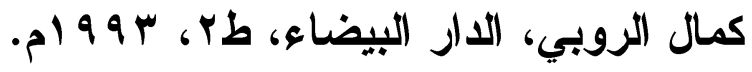

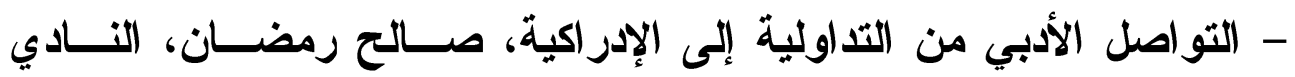

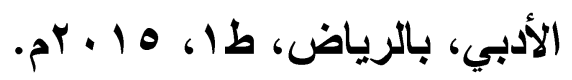

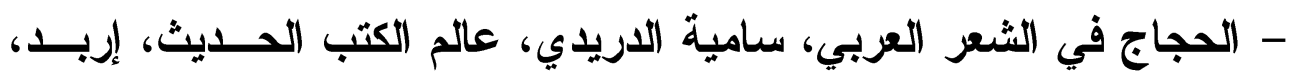

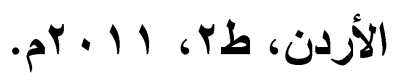




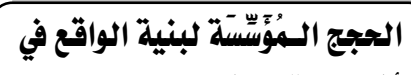

أخبار العقد الفريل لابن عبد ربله

- الحجاج في/الخطاب السياسي،الرسائل السياسية/الألدلسيةخلال القرن الهجري الخامس أنموذجًا، عبد العالي قادا، كنوز المعرفة، عمَّان، طا، 10 ـ بم. - الحجاج عند أرسطو، ضمن أهم نظريات الحجاج في التقاليا الغربية مسن أرسطو إلى اليوم، هشام الريفي، كلية الآداب، منوبة، تونس.

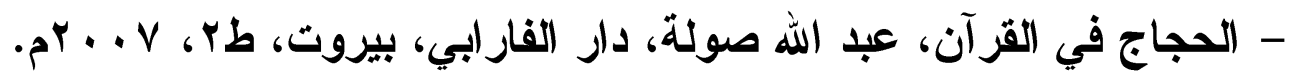
- الحجاج في اللغة والبلاغة، ديكرو وبيرلمان نموذجًا، أبو بكر العـزاوي،

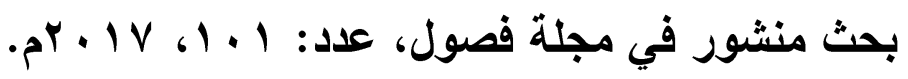

- حجاجية الصورة الفنية في الخطاب الحربي، "خطب الإمام علي أنموذجا"، علي عمران، دار نينوى، دمثق، طا، 9 ، . ب م.

- الحكاية والتأويل، عبدالفتاح كليطو، دار توبقال، الـــدار البيضــاء، طب، -p) 999 - الحيوان للجاحظ، تحقيق: عبد السلام هارون، دار إحياء التزاث العربـي،

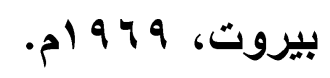

- خصائص الأسلوب في الشوقيات، محمد الطر ابلسي، منشورات الجامعــة

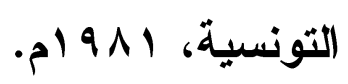

- الخطابة أرسطو طاليس، ثرجمة: عبدالرحمن بلوي، دار القلم، بيـروت، -p) $9 \vee 9$

- دلايل الإعجاز، عبد القاهر الجرجاني، قرأه وعلق عليه: محمود شــاكر،

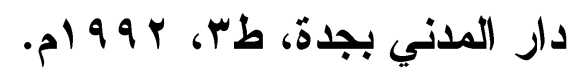

- الرسائل، الجاحظ، تحقيق: عبد السلام هارون، مكتبة الخــاتجي، مصــر، -p) $9 \vee 9$ - الصورة القتية،جابر عصفور،دار الكتاب المصري، القاهرة، طس . . ب، ام. 


\section{ISSN 2356-9050 الترقير الدولخ

- الصناعتين، أبو هلا العكري، تحقيق:علي البجاوي، المكتبة العصرية،

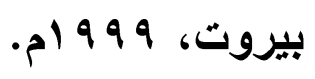

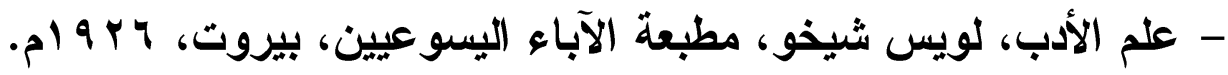
- عن بدايات الخطاب العربي الحديث نحو بلاغة موسوعية: محمد مشبال،

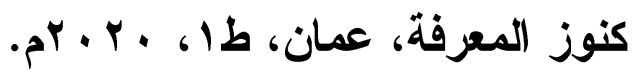

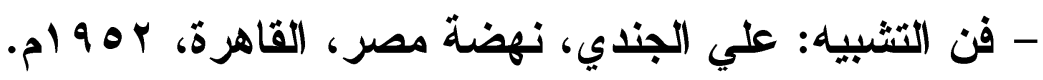

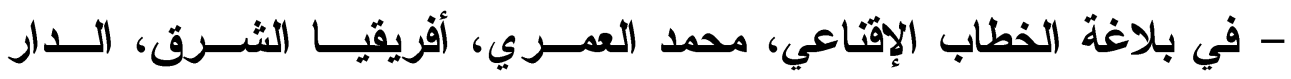

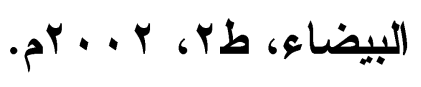

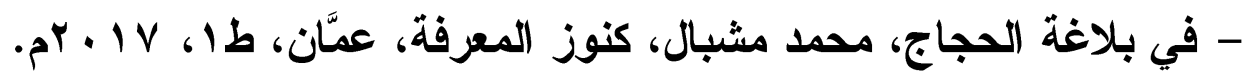

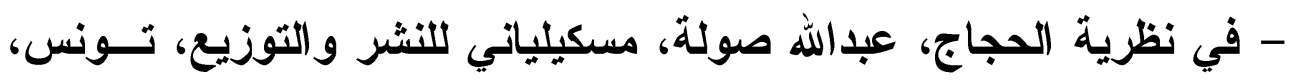

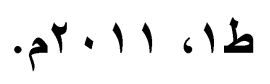

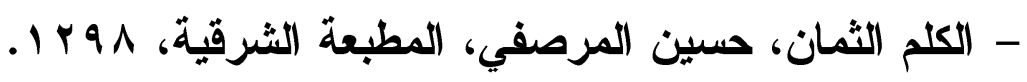

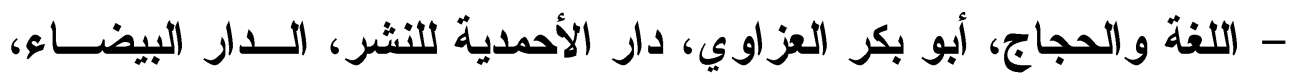

$$
\text { . . } 7
$$

- مقالتان في الحجاج، أبو بكر العزاوي، مارك بنوم، ترجمة: محمد البقالي،

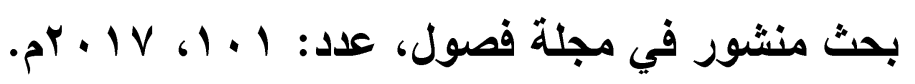

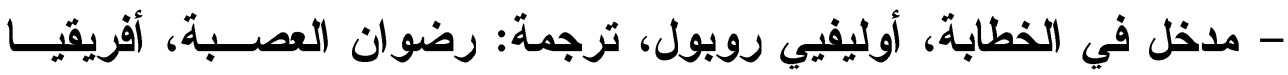

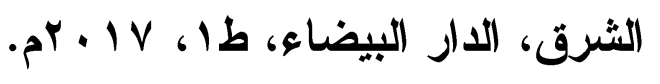

- منهاج البلغاء وسر اج الأدباء: حازم القرطاجني، تحقيق: محمد الحبيـب،

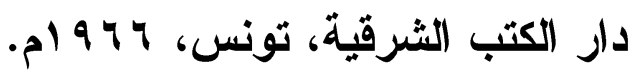

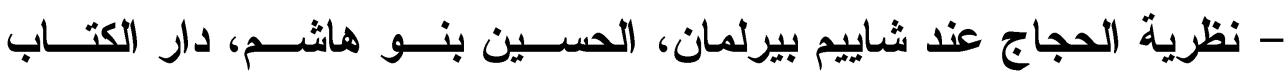

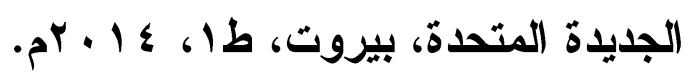




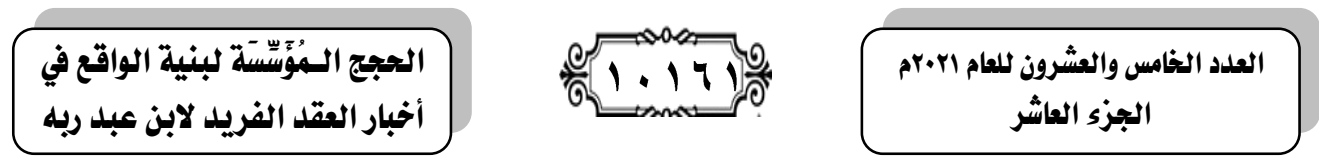

فهرس الموضوعات

\begin{tabular}{|c|c|c|}
\hline |الصفهة & الموضـوع & $p$ \\
\hline 1.111 & هلخص & -1 \\
\hline $1.11 r$ & Abstract & $-r$ \\
\hline $1.11 \%$ & المقدهة & $-r$ \\
\hline 1.119 & تمهيد : المنطلقات المجاجية & $-\varepsilon$ \\
\hline $1.11 \mathrm{~V}$ & ـ الوقائع & -0 \\
\hline $1.11 \mathrm{v}$ & ـ الهقائق & -7 \\
\hline 1.111 & ـ الافتراضات & $-\psi$ \\
\hline $1 \cdot 111$ & 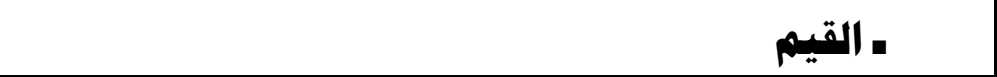 & $-\Lambda$ \\
\hline 1.111 & ـ النزاتبيات والهرهيات & -9 \\
\hline 1.119 & ـ المواضع & $-1 \cdot$ \\
\hline $1 . \mid r_{1}$ & المبحث الأول: تأسيس الواقع بواسطة الحالات الخاصة (المثال). & -11 \\
\hline $1.1 \mathrm{r}$ & المبحث الثاني: الهجاج بالصور البلاغية. & $-1 t$ \\
\hline 1.101 & هصادر البحث ومهراجعه & -14 \\
\hline 1.171 & فهرس الموضوعات & -18 \\
\hline
\end{tabular}

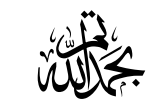

